\title{
MASSACRE DO CARANDIRU: VINTE ANOS SEM RESPONSABILIZAÇÃO*
}

\author{
LUISA MORAES ABREU FERREIRA, \\ MARTA Rodriguez de Assis MACHAdo \\ E MAÍRA ROCHA MACHADO
}

[*] Este texto expõe resultados parciais da pesquisa conduzida pelas autoras junto com a pesquisadora Carolina Cutrupi Ferreira, os estagiários Brenda Lima, Naiara Villardi eAnderson Lobo, no Núcleo de Estudos sobre o Crime e a Pena da Direito GV, com a colaboração da professora Flavia Püschel e dos alunos Pedro Mendonça, Luis Al-Contar e Mariana Marangoni. As autoras agradecem a todos os membros da equipe, aos defensores públicos Renata Tybiriçá, Carlos Weis e Juliana Belloque; à Rede 2 de Outubro, especialmente a Rodolfo Valente.

\author{
"Carandirué coisa do passado." \\ Antônio Ferreira Pinto, secretário de Segurança \\ Pública de São Paulo, ao nomear, em 2011, um dos réus \\ do processo criminal para comandar a Rota. \\ "Quem não reagiu está vivo." \\ Ex-governador Luiz Antônio Fleury Filho, ao comentar \\ o massacre às vésperas de completar vinte anos
}

\begin{abstract}
"Será que tem culpa o Estado dos presos se amotinarem, de desejar fugir, de desejar matar todos que se coloquem entre eles e a rua? A culpa foi das vítimas, que iniciaram a rebelião [...]. Enquanto na China são mortos 30 mil condenados de maior periculosidade por ano, enquanto em alouns países da América são mortos ou lançados na selva um grande número de presos irrecuperáveis, não se pode reclamar do Brasil, onde eles vivem protegidos da chuva e das necessidades alimentares, mantidos pelo Estado com dificuldades orçamentárias, que lhes dão privilégio em relação aos pobres pais de família de salário mínimo."

Desembargador Pinheiro Franco, do Tribunal de Justiça de São Paulo, ao negar pedido de indenização de Ionice Urbano da Luz, mãe de um dos presos mortos no massacre.
\end{abstract}

Passados vinte anos, nenhuma autoridade competente foi capaz de atribuir responsabilidades pelo Massacre do Carandiru. Apesar de diversos esforços da sociedade civil, os processos de responsabilização disciplinar, criminal, civil e internacional iniciados após o massacre foram interrompidos ou permanecem sem conclusão. No Brasil, os órgãos do sistema de justiça nem sequer chegaram a declarar formalmente que o episódio que levou (pelo menos) 111 cidadãos sob a custódia do Estado à morte se tratou de um massacre. Essa declara- 
ção veio apenas da Comissão Interamericana de Direitos Humanos da OEA ${ }^{1}$. A documentação produzida por nosso sistema de justiça continua referindo-se aos eventos do dia 2 de outubro de 1992 como "rebelião" ou "motim" do Pavilhão 9 daquela casa de detenção.

No Estado de direito, somente a decisão de responsabilização quebraria a teia de possíveis explicações sobre o que ocorreu naquela tarde e permitiria afirmar que o massacre não foi obra do destino, culpa dos próprios presos "amotinados" ou da fumaça, da escuridão e do piso escorregadio. Até agora, essas são explicações oferecidas para o que o promotor de justiça militar que atuou no caso descreveu como "verdadeira ação bélica, pois os policiais militares, fortemente armados, desencadearam a maior matança já consignada mundialmente em um presídio"2.

A Polícia Militar paulista mantém em seus quadros os réus que respondem criminalmente pela morte de 111 cidadãos em privação de liberdade e pelas lesões a outros 92. A maioria dos réus de maior patente àquela época (tenentes-coronéis, majores e capitães) figura atualmente no portal da transparência do governo estadual ${ }^{3}$ como coronel, patente de hierarquia superior - o que indica que os procedimentos disciplinares ou não foram concluídos, ou, caso tenham sido, não deram ensejo à sanção de expulsão. Dois deles foram recentemente nomeados comandantes da Ronda Ostensiva Tobias de Aguiar (Rota) pelo governador do estado de São Paulo Geraldo Alckmin 4 . A dúvida quanto à existência e ao desfecho dos processos disciplinares permanecerá enquanto não for franqueado acesso público aos autos desses procedimentos 5 .

O processo criminal que tramita perante o Tribunal do Júri em nenhum momento alcançou as pessoas que ocupavam as mais altas posições hierárquicas envolvidas na ordem de invasão do Pavilhão 9. Somente um dos dois únicos coronéis que figuraram como réus no processo criminal - cel. Ubiratan Guimarães - foi julgado. Condenado (a 632 anos de prisão) pelo júri, foi, no entanto, absolvido pelo Tribunal de Justiça de São Paulo cinco anos depois. Dezenas de réus denunciados no processo criminal devem começar a ser julgados na melhor das hipóteses somente a partir de 2013, uma vez que o processo esperou por dez anos que o Tribunal de Justiça de São Paulo confirmasse a decisão de pronúncia, que envia o caso ao plenário do júri.

Ao lado da responsabilização individual dos policiais, os familiares ainda buscam na justiça responsabilizar civilmente o estado de São Paulo pelo massacre, o que lhes daria direito a receber indenizações pela morte de filhos, companheiros e pais, que se encontravam sob a custódia do estado. Pelo que foi possível apurar até o momento, apenas 66 famílias iniciaram processos de responsabilização civil e, dessas, somente 34 conseguiram vencer o processo judicial e a fila dos
[1] OEA, Relatório 34/oo de 13.04.2000, Caso 11.291 (Carandiru).

[2] Ação penal n. 0338975-6o. 1996.8.26.0001, fls. 29. A não ser que outra fonte esteja expressamente indicada, todas as citações documentais referem-se a essa ação penal, em trâmite perante a $2^{\mathrm{a}}$ Vara do Tribunal do Júri da Capital, no Foro Regional de Santana, primeira instância da Justiça Estadual do Estado de São Paulo. Além dos autos dessa ação penal, composta de 55 volumes, este texto baseia-se também nos acórdãos dos recursos interpostos perante o Tribunal de Justiça do Estado de São Paulo, obtidos por meio do sistema de busca eletrônica do tribunal.

[3] Disponível em: 〈http://www. transparencia.sp.gov.br/pessoal. html>.

[4] Salvador Modesto Madia foi nomeado comandante da Rota em setembro de 2011 e, após um ano no cargo, foi substituído por Nivaldo Cesar Restivo, ambos denunciados pelo Ministério Público no processo criminal de apuração de responsabilidade pelo massacre.

[5] A fim de obter acesso aos eventuais procedimentos, concluídos ou em trâmite, o Núcleo de Estudos sobre o Crime e a Pena, com base na Lei de Acesso à Informação (Lei n. 12.527/2011), formulou pedido de vista ao corregedor da Polícia Militar. O objetivo do pedido é conhecer o modo como a própria instituição policial geriu internamente a participação de seus quadros no Massacre do Carandiru. Tal pedido, contudo, foi indeferido pelo coronel da PM corregedor Rui Conegundes de Souza, sob a alegação, em síntese, de que as informações solicitadas seriam "informações pessoais" e não teria sido comprovado o consentimento expresso das pessoas a que se referem ou o evidente interesse público ou geral da informação. Em face do indeferimento do pedido, em 10 de setembro de 2012, o Núcleo interpôs recurso ao subcomandante da Polícia Militar do Estado de São Paulo coronel Hudson Tabajara Camilli, argumentando que (i) processos disciplinares contra funcionários públicos não são "informações pessoais" relacionadas à honra e à intimidade; (ii) ainda que fossem considerados 
informações pessoais, a Lei de Acesso à Informação permite o acesso a tais documentos por se tratar de “informações necessárias à defesa de direitos humanos e proteção do interesse público e geral". O recurso foi negado com base em argumentos semelhantes à decisão anterior. O Núcleo interpôs então recurso ao presidente da Corregedoria Geral da Administração do Estado de São Paulo, que no último dia 13 de novembro decidiu pelo provimento, permitindo acesso aos processos disciplinares já concluídos. O Comando Geral da Polícia Militar já foi comunicado de tal decisão por ofício da Corregedoria e estamos iniciando os trâmites para ter acesso aos processos.

[6] No entanto não podemos afirmar que essas 34 famílias já tenham recebido o dinheiro. Segundo informações obtidas na Defensoria Pública, exige-se ainda uma série de outras providências burocráticas para que um precatório seja efetivamente pago, como, por exemplo, a abertura de uma conta específica e individualizada para cada beneficiário em instituição bancária oficial (Banco do Brasil).

[7] Mas nem sempre.é possível verificar em nossa jurisprudência contemporânea a utilização da responsabilidade civil com fins punitivos. Cf. Püschel, F. P. “Funções e princípios justificadores da responsabilidade civil e o art. 927, parágrafo único, do Código Civil". In: Rodriguez, J. R., Püschel, F. P. e Machado, M. R. A. Dogmática é conflito. Uma visão crítica da racionalidade jurídica. São Paulo: Saraiva, 2012. precatórios para ter o dinheiro das indenizações finalmente disponibilizado. E isso ocorreu apenas em $2011^{6}$.

No âmbito do sistema interamericano de proteção dos direitos humanos, o Estado brasileiro foi considerado responsável pela violação do direito à vida e à integridade física de cidadãos que estavam sob sua responsabilidade. Mas, ao mesmo tempo, o caso deixou de ser enviado a julgamento pela Corte e o relatório publicado em 2000 limitou-se a emitir recomendações para que fossem concluídas as investigações, indenizados os familiares e melhoradas as condições carcerárias. Desde então, os planos de expansão do sistema penitenciário estão longe de reduzir o quadro de superpopulação prisional no estado de São Paulo e são crescentes as alegações de violência e arbitrariedade por parte da Polícia Militar paulista. Esse panorama indica que vinte anos após a ocorrência do massacre, as instituições do sistema de justiça - brasileiras e internacionais - foram incapazes de atribuir responsabilidades e de reverter as condições objetivas que permitiram que ele ocorresse.

\section{RESPONSABILIZAÇÃO}

A necessidade de responsabilização refere-se à demanda de que uma determinada consequência seja ligada à ação ou omissão de uma pessoa (individual ou coletiva) e, no caso, compreendida como ilegítima, ilícita e indesejável. Isso se dá por meio de processos sociais de construção de sentido, e o direito é um deles. No mundo jurídico, um mesmo ato pode configurar um ilícito administrativo-disciplinar, um ilícito civil e um ilícito penal. A cada um deles correspondem procedimentos, critérios e consequências distintas. As regras de atribuição de responsabilidade também são diferentes e variam em função dos objetivos de cada tipo de processo decisório.

No direito civil, um órgão coletivo como uma empresa ou um Estado pode ser declarado responsável por uma ação que não lhes seja diretamente imputada. Há critérios de imputação por ações de outros, por exemplo. É possível também imputar civilmente sem culpa, apenas segundo o critério de quem está mais bem posicionado ou tem mais condições de arcar com os custos da responsabilização, porque, a princípio, a responsabilidade civil está ligada ao dever de indenizar7.

$\mathrm{Na}$ configuração de nosso sistema de responsabilização, a análise da conduta individual (ação ou omissão) dos envolvidos em um ato ilícito pode ser feita tanto na esfera administrativo-disciplinar como na esfera penal. Aqui não está em jogo a responsabilidade do Estado diante das consequências, mas a conformidade das condutas individuais com a ordem jurídica, no primeiro caso, de acordo com o estatuto da corporação a que está vinculado, e, no segundo, com a lei penal. 
Este texto expõe os resultados preliminares de um projeto de pesquisa em curso sobre a atuação do sistema de justiça no caso do Massacre do Carandiru e prioriza um desses mecanismos de responsabilização: o processo criminal, a partir da análise integral dos autos da ação penal movida contra os policiais militares envolvidos na ação. O objetivo é compreender a construção das imputações, desvendar os processos decisórios e identificar de que modo diferentes atores do sistema de justiça intervieram nesse caso. Sobretudo, interessa explorar as implicações que fatores externos ao processo - como a aprovação da Lei Bicudo ${ }^{8}$ e a eleição de Ubiratan - tiveram no fluxo processual.

O texto está dividido em três partes. A primeira apresenta uma narrativa da ação penal, desde o inquérito penal militar até o momento processual em que o caso se encontra vinte anos após o massacre. A seção seguinte reorganiza as condutas, as imputações e as penas em função do cálculo da prescrição dos crimes imputados aos policiais militares e, desse modo, discute alguns possíveis desfechos que o caso pode vir a ter. A terceira e última parte sistematiza os resultados obtidos e, a partir das recomendações que a Comissão Interamericana de Direitos Humanos formulou em 2000 , apresenta um balanço da (in) capacidade do Estado brasileiro de responsabilizar os envolvidos e modificar as condições objetivas para que episódios semelhantes não voltem a acontecer.

\section{CARANDIRU: OS PROCESSOS CRIMINAIS}

O processo jurisdicional é composto de uma série de decisões que reconstroem os fatos a partir das provas existentes nos autos, selecionam as pessoas às quais esses fatos podem ser atribuídos e indicam as normas que teriam sido violadas por essas pessoas naquele contexto. No caso do Massacre do Carandiru, como em inúmeros outros casos complexos, várias instituições do sistema de justiça participaram em diferentes etapas do processo. Exporemos essas etapas, colocando em destaque a maneira como cada uma dessas instituições formatou a versão jurídica dos fatos e contribuiu para a possível conclusão do caso. A narrativa do processo segue seu desenvolvimento cronológico e foi organizada em seis partes: o inquérito policial militar no comando geral da PM; a denúncia pelo promotor de justiça militar; a instrução do processo criminal — que começou na justiça militar estadual e foi deslocado para a justiça criminal comum (vara do Tribunal do Júri) em razão da Lei Bicudo - ; o julgamento do cel. Ubiratan pelo júri; e a atuação do Tribunal de Justiça de São Paulo (TJSP) tanto para reverter a condenação de Ubiratan como para confirmar a pronúncia no processo original.
[8] A Lei 9.299/1996, também conhecida como "Lei Bicudo", alterou o Código Penal Militar (Dec.-Lei 1.001/1969) e o Código de Processo Penal Militar (Dec.-Lei 1.002/1969) ao estabelecer a competência da justiça comum para processar e julgar crimes dolosos contra a vida praticados por militares contra civis. 
[9] A instauração de inquérito policial militar (e não civil) se deu com fundamento no artigo 9, II, "c" e " $f$ " do Código Penal Militar, que, na época, determinava a competência da justiça militar para julgar crimes praticados por militar em serviço, ou com o uso de armamento militar, contra civil (fls. 24). Essas alíneas foram revogadas com a aprovação da Lei 9.299/96, que passou a determinar a competência da justiça comum para o julgamento de crimes praticados por militares, quando dolosos contra a vida e praticados contra civil.

[10] O coronel Eduardo Assumpção será, ao final do inquérito policial militar, o responsável por assinar a "Solução do IPM", último documento desse inquérito. Nesse documento, o comando geral da PM homologa o relatório final do inquérito, faz considerações sobre responsabilização e determina a remessa dos autos à justiça militar, para manifestação do promotor de justiça militar (fls. 4094-4104).

[11] Documento que marca o início de um inquérito policial, resumindo as informações obtidas até então e o possível fato criminoso que será investigado. Embora não tenham forma rígida prevista em lei, os inquéritos policiais (civis ou militares) costumam ter o seguinte formato: (i) portaria de instauração; (ii) documentos produzidos durante as investigações, como depoimentos e perícias; e (iii) relatório final, assinado pelo responsável pela condução do inquérito, com um resumo do que foi investigado (art.10, §1으, do CPP)e, em alguns casos, uma conclusão.

[12] Fl. 92.

[13] O Comando de Policiamento de Choque, ou "tropa de choque", é o agrupamento de Batalhões de Choque da Polícia Militar.

[14] Fls. 93-95. A questão dos treze revólveres apreendidos é controversa. No relatório do inquérito policial militar "verificou-se nos autos uma certa polêmica à [sic] respeito das referidas armas [13 armas apreendidas pelos policiais militares], pois, ouvidos os presos, grande parte declarou que foram colocadas pelos próprios policiais militares no pavilhão 9 ". O relatório, em seguida, descarta a possibilidade levantada pelos presos,

\section{A INVESTIGAÇÃO DA POLÍCIA NA POLÍCIA PELA POLÍCIA}

O início da atuação do sistema de justiça em relação ao caso se deu no dia seguinte ao massacre, com a instauração do inquérito policial militar` pelo comandante geral da Polícia Militar à época, cel. Eduardo Assumpção $0^{10}$. De acordo com a portaria de instauração $0^{11}$, o inquérito teria como objetivo apurar "confronto entre presos do pavilhão 9 da Casa de Detenção de São Paulo, exigindo a intervenção de forças policiais militares de diversas unidades, as quais foram obrigadas a fazer uso de armas de fogo para conter os rebeldes"12.

A portaria de instauração das investigações trazia consigo o relatório da operação "para conter a Rebelião na casa de detenção" elaborado naquele mesmo dia ( 3 de outubro) pelo Comando de Policiamento de Choque ${ }^{13}$. Tal relatório indica que, após briga de "gangues rivais", houve confronto generalizado que tornou a situação "incontrolável". A tropa de choque, segundo o documento, teve autorização para a entrada no pavilhão e "foi recebida a tiros, pedaços de pau, pedaços de ferro, facas contaminadas com sangue dos aidéticos, sacos plásticos contendo urina; bem como vários policiais militares entraram em contato corpo a corpo com os presidiários". Ainda de acordo com o relatório "o motim foi controlado mediante ação de choque, contudo houve necessidade de fazer uma conferência dos presidiários, limpeza das instalações, avaliação dos mortos e feridos, coleta de material ilícito para perícia e comunicar o resultado às autoridades competentes". Esse documento descreve como "resultado da operação": "22 policiais militares feridos; 111 presidiários mortos; 13 revólveres apreendidos; 165 estiletes de ferro; 25 pedaços de ferro (cano); 1 marreta de ferro; porções de cocaína, e porções de maconha" ${ }^{14}$. Nenhum policial militar posteriormente denunciado pelo promotor de justiça militar foi mencionado nesse primeiro relatório.

Em menos de um ano, o inquérito policial militar foi concluído, tendo sido realizada e juntada aos autos uma série de laudos do Instituto de Criminalística do Departamento Estadual de Polícia Civil e do Instituto Médico Legal'15 e ouvidas 469 pessoas, entre "ofendidos PMs" (7 oficiais e 16 praças ${ }^{16}$ que foram feridos durante a operação, como o cel. Ubiratan); "ofendidos detentos" (9o presos vítimas de ferimentos); e "testemunhas" ${ }^{17}$. As "testemunhas" foram divididas em três grupos principais: "praças que entraram no pavilhão 9 e atiraram" (55); "oficiais do batalhão de choque" (46); e "praças" que não atiraram, que não entraram no pavilhão e outras testemunhas civis $(251)^{18}$.

As versões dos policiais militares e dos presos são, em geral, conflitantes. De acordo com síntese feita posteriormente pelo juiz que decidiu sobre a pronúncia dos réus ${ }^{19}$, os policiais "dizem que atiraram em revide às agressões que recebiam, apontando, ainda, as dificulda- 
des encontradas no decorrer da operação, principalmente em razão da fumaça, escuridão e piso escorregadio". Ainda de acordo com o juiz, "negaram ter disparado contra presos quando estes estavam no interior de suas celas" e "infere-se que os tiros que efetuaram tinham também o objetivo de intimidar os detentos, fazendo com que retornassem para suas celas" 20 . Os presos negam confronto e dizem que se sentaram no chão com as mãos na cabeça assim que a polícia entrou no pavilhão ${ }^{21}$.Alguns afirmam terem visto policiais atirando diretamente em presos ${ }^{22}$; outros afirmam terem sido espancados ao andar pelos corredores em direção ao térreo ${ }^{23}$.

O exame de levantamento do local (constante dos laudos periciais e fator mais citado nas decisões sobre a imputação criminal) concluiu que a trajetória dos projéteis indicou "atirador(es) posicionado(s) na soleira da respectiva porta, apontando sua arma para os fundos ou laterais" e que "não se observou quaisquer vestígios que pudessem denotar disparos de arma de fogo realizados em sentidos opostos aos descritos, indicando confronto entre as vítimas-alvo e os atiradores postados na parte anterior da cela". O laudo conclui, por fim, que o início da operação da Polícia Militar foi marcado por "tumulto generalizado, com a carceragem central em chamas" e que "pode-se inferir que o propósito principal da operação policial militar foi o de conduzir parte dos detentos à incapacitação imediata". Outra informação importante trazida pelo laudo de local é a de que teria ficado "evidente que referida ação foi dirigida contra grupos de reação perseguidos pelos policiais", em razão da constatação de diversas celas sem qualquer tiro e "seus ocupantes incólumes"24.

Os laudos serviram de base para o parecer médico-legal realizado pelo Departamento de Medicina Legal da Faculdade de Medicina da Universidade de São Paulo, requisitado por Paulo Sérgio Pinheiro ${ }^{25}$. Esse documento foi juntado ao processo posteriormente e traz dados importantes para a aferição da violência da ação policial. Ao analisar os laudos do IML, o parecer conclui que grande parte dos presos mortos foi atingida por mais de cinco projéteis ${ }^{26}$ e que quase todas as vítimas que receberam tiros morreram ${ }^{27}$.

Não obstante sua importância para esclarecimento das circunstâncias dos crimes, há pelo menos duas limitações graves nos exames necessários ao esclarecimento do caso: a notável falta de preservação do local do crime e a incapacidade técnica do Instituto de Criminalística de realizar o laudo de confronto balístico.

Os peritos que realizaram o exame do local consignaram que "todo um somatório de conclusões a respeito do evento, bem como mais profundos pormenores, deixam de ser apresentados neste laudo, em virtude do fato de que o local dava nítidas demonstrações de que fora violado, tornando-o inidôneo para a perícia" ${ }^{28}$. A falta de cuidado com concluindo que "era de se esperar que os presos não iriam admitir de forma alguma que estavam portando armas de fogo. Uma negativa já esperada e normal".

[15] Foram acostados os seguintes laudos: "Laudo de exame de corpo de delito: policiais militares feridos; detentos feridos", "Laudo de exame necroscópico (detentos)", "Laudo de exame macroscópico de projéteis", "Laudos de exame de armas de fogo e peças apreendidas na Casa de Detenção", "Laudo de exame de peças utilizadas pelos policiais militares na operação", "Laudo de exame pericial de levantamento do local".

[16] São considerados "oficiais" os policiais militares com cargos de coronel, tenente-coronel, major, capitão, primeiro-tenente e segundo-tenente. Os "praças" são subtenente, sargento, cabo e soldado.

[17] Essa classificação é feita no Relatório Final do Inquérito Policial Militar, que sistematizou as informações produzidas durante as investigações.

[18] Essa distinção entre policiais militares que atiraram e que não atiraram é importante e será retomada nas conclusões do Relatório Final como único critério para a definição de quem, na opinião do encarregado do inquérito, deveria ser denunciado.

[19] Essa síntese diz respeito, principalmente, aos interrogatórios judiciais, mas a leitura dos depoimentos na polícia já indica ser essa a versão dos fatos como contada pelos policiais, desde o início do inquérito.

[20] Fls. 8334-8335.

[21] "Assim que os PM chegaram saíram com as mãos sobre a cabeça olhando para o chão"; "estava no xadrez mencionado com mais 4 detentos de nome, Donizette, José e o vulgo Gabiru e o Paulo Henrique, sendo que por volta das 18:30 horas, o Choque da PM entrou no Pavilhão 9 e o declarante viu um $\mathrm{PM}$ que chegou na sua cela, batendo com o cano do revolver no guichê, dando ordem para que todos tirassem as roupas e saíssem com as mãos na cabeça" (Relatório Final do Inquérito Policial Militar, fls.3918-3937). 
[22] "Chegou um PM em sua cela e ordenou que todos saíssem, porém antes se deitassem e que após deitados esse PM disparou uma rajada dentro da cela, vindo a ferir mortalmente o detento Claudio Nascimento da Silva" (Relatório Final do Inquérito Policial Militar, fls.3918-3937).

[23] "Quando descia notou que alguns detentos eram retirados da fila para a faxina e que também levou algumas cassetadas e pauladas"; "um PM que portava metralhadora determinou que todos saíssem das celas, deitassem no corredor e posteriormente se despissem e rumassem para o pátio, sendo no percurso agredidos pelos PM que portavam armas brancas"; "passaram por um corredor formado por PM e tomaram chutes e golpes de cassetetes"; "No pavimento térreo o declarante teve que passar por um corredor polonês, formado por vários PM, quando recebeu chutes e golpes de cassetete" (Relatório Final do Inquérito Policial Militar, fls. 3918-3937).

[24] Fls.1170-1173.

[25] Fls. 4270-4274.

[26] Dos 111 mortos, 93 receberam três ou mais disparos e, desses, 57 foram atingidos por cinco ou mais projéteis; três presos levaram nove tiros; outros três levaram treze tiros cada um; um preso levou dezesseis tiros.

[27] Das 106 vítimas atingidas por arma de fogo, 102 morreram.

[28] Fls. 1170-1173.

[29] Relatório final do IPM, sobre o laudo pericial realizado (fls. 4024-4035).

[30] Vale mencionar que esta perícia permitiria determinar de qual arma se disparou o tiro ou os tiros que acarretaram a morte de qual detento. Em outras palavras, seria o instrumento técnico que permitiria que se individualizasse a responsabilidade pelas mortes, o que, como será explicado abaixo, não foi feito na denúncia.

[31] "O I.C. constatou que seria necessária a realização de 61.280 exames de confronto balístico, ou seja, 383 armas multiplicados por 130 projéteis, fator que tornou inviável a realização dos referidos exames; visto a preservação das provas é notada ainda no laudo de exame das armas de fogo, em que os peritos atestam que a pesquisa de resíduos de pólvora combusta nas armas relacionadas ficou prejudicada "face ao tempo decorrido entre a data da ocorrência e a do recebimento das mesmas no I.C., tendo em conta a pouca estabilidade dos produtos oriundos da combustão da pólvora". O laudo conclui, assim, que "a perícia não pode afirmar se as mencionadas armas atiraram recentemente" 29 .

Ainda mais preocupante é a questão do exame de confronto balístico ${ }^{30}$. Esse exame, embora requerido pela autoridade militar que conduziu o inquérito, não foi feito em razão de dificuldades técnicas apontadas pelos peritos do Instituto de Criminalística ${ }^{31}$. Ao longo dos vinte anos de processo criminal, a defesa requisitou repetidamente a realização desse exame: na decisão de pronúncia, o juiz entende que o laudo, além de inviável, seria desnecessário naquela fase processual, mas poderia ser realizado antes do julgamento pelo júri3². Em $2012-$ já na fase que antecede o julgamento - a juíza competente determina a realização do laudo. Como será explicado adiante, essa decisão foi revista às vésperas de o massacre completar vinte anos.

Encerradas as investigações - principalmente depoimentos elaudos - dois documentos foram elaborados pela Polícia Militar para organizar os fatos, pessoas envolvidas e possíveis normas violadas. O primeiro é o Relatório Final elaborado pelo coronel da PM encarregado do inquérito em janeiro de 1993. Esse documento é seguido da Solução do IPM, elaborado pelo comando geral da PM, outra espécie de relatório (mais sucinto e conclusivo), que tem como objetivo "homologar" o Relatório Final.

As conclusões preliminares do Relatório Final enfatizam dificuldades que teriam sido enfrentadas pelos policiais militares que entraram no Pavilhão 9: possibilidade de fuga de presos ${ }^{33}$, medo de infecção por aids ${ }^{34}$, visibilidade ruim ${ }^{35}$ e vontade dos presos de enfrentamento com os policiais ${ }^{36}$. Conclui que a entrada da Polícia Militar foi feita "dentro de um contexto de total legalidade e devidamente autorizado pelo secretário de Segurança Pública", em estrito cumprimento de dever legal e legítima defesa ${ }^{37}$. No entanto, embora tenha considerado necessária a entrada da PM, o relatório indica que a operação "foi executada com excessos", especialmente diante da prova pericial que demonstra que foram disparados tiros dentro das celas. ${ }^{38}$

É na indicação de quem seriam os policiais militares responsáveis pelos "excessos" que aparece pela primeira vez a dificuldade da individualização das condutas. Em razão da impossibilidade de realização de exame de confronto balístico, são mencionados como possíveis responsáveis aqueles que segundo autodeclaração "dispararam suas armas" 39 . Nessa lista, não há nenhum coronel, tenente-coronel ou major. 
A Solução do IPM traz conclusões parecidas. De acordo com o comando geral da PM, "o plano tático montado pelo Cel. Ubiratan Guimarães, ao nosso ver foi perfeito, não havendo excesso de ação policial, no que tange ao ingresso da Tropa no Pavilhão Nove". O documento afirma expressamente que não há indício da prática de crime pelos oficiais superiores (coronéis Ubiratan e Parreira, responsáveis pelo comando da tropa, bem como os tenentes-coronéis Chiari, Faroro e Nakaharada, comandantes dos Batalhões de Choque). Admite-se possível excesso na ação policial, mas "motivado provavelmente pelo excesso de obstáculos colocados pelos presos, como resistência à ação policial, os quais valeram-se para tanto de uma série de recursos delituosos" 40 .

Por fim, a Solução do IPM discorre sobre possíveis crimes cometidos pelos presos durante a operação e conclui: "Enfim estamos plenamente convencidos de que tais comportamentos delituosos por parte dos presos serão devidamente analisados e levados em conta pela Justiça Comum e certamente servirão de parâmetro para que a Justiça Militar analise as condições totalmente adversas, encontradas pelos Policiais Militares, para cumprir suas responsabilidades legais" 4 .

Essa versão dos fatos, bem como a imputação de responsabilidades a oficiais superiores, é modificada de maneira bastante significativa, três meses depois, na versão oferecida pelo promotor de justiça militar em sua denúncia. Interessante notar que essa peça processual foi elaborada com base nos mesmos documentos - laudos e depoimentos produzidos ao longo do inquérito policial militar - que ensejaram o Relatório Final e a Solução do IPM.

\section{A VIRADA NAS IMPUTAÇÕES E A DENÚNCIA POR GRUPOS}

Em março de 1993, o promotor de justiça militar Luiz Roque Lombardo Barbosa ofereceu denúncia contra 120 policiais militares envolvidos no massacre ${ }^{42}$, afirmando, na peça inicial da ação penal, ter o episódio se tratado de "verdadeira ação bélica, pois os policiais militares, fortemente armados, desencadearam a maior matança já consignada mundialmente em um presídio". De acordo com a denúncia, "as penas privativas de liberdade a que estavam sujeitos os detentos, transformaram-se, arbitrária eilicitamente - em penas capitais - 111 (centoe onze) mortos". Pela primeira vez no procedimento criminal, afirma-se que a operação não foi simplesmente excessiva, mas sim "desastrosa". De acordo com o promotor, não havia risco de fuga dos presos, não houve estratégia ou planejamento por parte dos comandantes e os policiais militares teriam entrado no pavilhão com "animus necandi" (vontade de matar)43. que este é realizado em aparelhagem específica, por inspeção e pesquisa, ocular e individual, das características microscópicas dos projéteis, em busca de uma associação de elementos de certeza. Deste modo, torna-se imprevisível o tempo necessário para realização de um único exame de confronto. Segundo o I.C., tal quadro se agrava, considerando-se que sua demanda, neste tipo de perícia, conforme registros, é de cerca de 100 (cem) laudos por mês, em atendimento a Capital e Interior do estado, produção esta decorrente do grau de dificuldade já exposto" (Relatório final do IPM, sobre o laudo pericial realizado - fls.4024-4035).

[32] "A defesa insiste no pedido de confronto balístico mas esta prova a um só tempo mostra-se inviável no presente momento e, de outra parte, não é imprescindível para o exame que agora se faz, objetivando verificar se é o caso de pronúncia ou não e, decidindo-se pela primeira hipótese, nada impede que esta prova seja colhida em outro instante, antes do julgamento em Plenário" (fls. 9569-9570).

[33] "Diante da provável tentativa de fuga em massa e do alastramento da rebelião para outros pavilhões, não restou outra alternativa à tropa de choque da Polícia Militar, senão ingressar no pavilhão 9 , sob pena de ser responsabilizada por omissão, pelos poderes constituídos e pela própria opinião pública" (fls. 4038-4047).

[34] "O que ficou claro, quando das oitivas dos oficiais praças do policiamento de Choque, que efetivamente entraram no Pavilhão 9 e se confrontaram com os presos, foi o medo ou até mesmo verdadeiro pavor de uma provável contaminação pelo vírus da aids, doença sem cura, que apavora a todos. É voz corrente que grande parte dos presos da Casa de Detenção está contaminada pelo vírus da aids, sendo exaustivamente divulgado pelos meios de comunicação falada, escrita e televisionada e em qualquer confronto, o risco de contágio" (fls. 4038-4047).

[35] “Consta também que os presos além de danificarem a rede hidráulica do prédio, inundando as galerias, as escadas e o piso, quebraram a rede elétrica, deixando o ambiente às escuras, dificultando a visibilidade, assim 
como atearam fogo nos colchões e objetos, provocando intensa fumaça" (fls. 4038-4047).

[36] "Ficou evidenciado nos autos que os presos previamente haviam se armado com mais de três centenas de instrumentos improvisados para agressão, tais como espadas artesanais feitas de seguimentos de cantoneiras metálicas de vitrôs, estiletes, mais precisamente doze estiletes e um serrote, tudo de fabricação artesanal, uma marreta de malho e cabo tubular, vinte e cinco seguimentos de cano metálico próprio para tubulação de água e cento e sessenta e cinco espadas artesanais feitas com seguimentos de cantoneiras metálicas de vitrôs e janelas. [...] Diante destas evidências não se pode descartar a hipótese de que havia 'animus' dos presos de enfrentamento dos policiais e de dificultar-lhes a ação" (fls. 4038-4047).

[37] Fls. 4038-4047.

[38] Fls.4039-4055.

[39] "De outro lado ficou evidente nos autos que ficou prejudicada a individualização da conduta dos policiais militares que entraram no Pavilhão 9, dispararam suas armas e mataram detentos. [...] só nos resta arrolar e apontar para a autoridade Policial Militar delegante aqueles que entraram no Pavilhão 9 e dispararam suas armas, dentre os quais estarão a parcela de policiais responsáveis pelos excessos já aduzidos e constatados pela perícia técnica e que, a critério do Ministério Público, devam ser denunciados à Justiça Militar" (fl. 4049). A leitura do Relatório Final dá a entender que, diante da controvérsia acerca de quem atirou, utilizou-se a autodeclaração do policial: "Por outro lado não temos em mãos o exame de confronto balístico, impossível de ser feito face ao grande número de armas utilizadas pela PM e o tempo que seria gasto para tal exame (fls. 194, vol. I), portanto não há condição do indiciamento de Polícias Militares, reconhecendo que ficou apurado indícios da prática de Crime Militar, indicando a seguir os Policiais Militares que declararam haverem efetuado disparos de arma de fogo no interior do pavilhão 9 " (fl.4048).

[40] Fls. 4101-4103.
Além da diferença substancial na composição dos fatos, a situação processual dos policiais militares de maior patente é transformada de forma radical.

De acordo com o Relatório Final, não haveria prova de que os sete oficiais superiores que comandaram a operação ${ }^{44}$ dispararam suas armas ${ }^{45}$. Não foram, portanto, incluídos na lista das pessoas sob as quais haveria indício de prática de crime. A Solução do IPM acompanha parcialmente essa conclusão ao afirmar que os cinco coronéis e tenentes-coronéis 46 "agiram dentro dos limites legais e cumpriram suas responsabilidades, não havendo, portanto, indícios da prática de crime militar pelos mencionados Oficiais Superiores"47.

Com a chegada dos autos do processo ao promotor de justiça a configuração da acusação foi alterada: todos os dezoito oficiais de maior patente foram denunciados, isto é, a conduta de cada um deles foi associada à violação de normas penais e aos resultados de morte e lesão das vítimas. Ao cel. Ubiratan foram imputadas as mortes por conduta dolosa, na modalidade "dolo eventual" - figura que o direito penal equipara ao dolo direto (intenção direta de produzir o resultado lesivo) e que se caracteriza pela existência de previsibilidade do resultado e pela decisão de realizar a ação apesar da previsibilidade ${ }^{48}$.

É importante mencionar que é na denúncia que a dificuldade de individualização das condutas aparece novamente. Para proceder à imputação de homicídios e lesões corporais aos membros da Polícia Militar o promotor procedeu da seguinte maneira:em primeiro lugar, dividiu a ação em duas etapas - a "retomada" dos pavimentos 49 e a "varredura" - e, em seguida, buscou distinguir as ações dos grupos.

De acordo com a denúncia, na primeira fase de atuação, ao retomar os pavimentos, "os grupos de Policiais declinados mataram e tentaram matar, mediante disparos de projéteis de armas de fogo e emprego de instrumentos pérfuro-cortantes", 116 presos (111 morreram e cinco sobreviveram) so. A responsabilização nessa primeira fase se deu pela vinculação das tropas que atuaram por pavimento às vítimas de cada pavimento. Aos policiais que participaram da "retomada do segundo pavimento" foram imputadas as mortes relativas aos corpos encontrados no segundo pavimento, e assim por diante. Com exceção do cel. Ubiratan, nessa fase não houve imputação dos oficiais superiores (coronéis, tenentes-coronéis e majores), já que a retomada dos pavimentos teria sido comandada diretamente por capitães da Polícia Militar ${ }^{11}$ e seu efetivo composto de tenentes, soldados e cabos. Além de Ubiratan, o único oficial superior denunciado por atuação nessa fase é Luiz Nakaharada, que, em razão de sua origem japonesa, é reconhecido por várias testemunhas como o policial que entrou na cela $339-\mathrm{E}$ (do $3^{\circ}$ pavimento) e matou, com metralhadora, os cinco presos que lá estavam. 
A segunda fase de atuação - chamada de "varredura" na denúncia - "consistiu na coordenação, acompanhamento, fiscalização e triagem dos detentos, por ocasião da movimentação de descida para o pátio e subida de retorno às respectivas celas". Nessa movimentação, os policiais teriam formado "corredor polonês", agredindo os presos, por meio de espancamento com instrumentos contundentes, ferimentos por instrumentos pérfuro-cortantes (facas, estiletes, baionetas) e mordidas de cachorro52. O resultado dessa segunda fase são lesões corporais em 87 presos. Nesse caso, o promotor entendeu que os policiais não agiram com intenção de matar e, por isso, as condutas foram classificadas como lesões corporais, e não como tentativa de homicídio.

No total, 32 policiais militares - entre oficiais e praças - foram responsabilizados pelas lesões causadas na "varredura". Embora, de acordo com a denúncia, apenas praças participaram diretamente do "corredor polonês", os oficiais também deveriam ser responsabilizados porque, no papel de "coordenação direta da movimentação de descida e subida de reclusos às celas", tinham dever jurídico de "obstaculizar o danoso evento". Nos termos da denúncia, os oficiais, "ao invés de conferirem proteção aos rendidos, permitiram vergonhosa sessão de espancamentos" 53 .

O quadro a seguir sintetiza o agrupamento feito pela denúncia para imputação das mortes e lesões.

Não obstante o trabalho realizado pelo promotor para reconstruir os fatos a partir dos depoimentos, as menções envolvendo ações individualizadas deram-se apenas em relação ao comando da operação pelo coronel Ubiratan, ao comando exercido pelos oficiais na segunda fase de atuação, ao tenente-coronel Luiz Nakaharada e a três policiais do "Canil", em relação aos presos que levaram mordidas de cães. De resto, as informações relativas à atuação dos denunciados na operação foram narradas e imputadas por grupos 54 , o que chama a atenção, pois no direito penal vige o princípio da imputação e culpa individuais. Com a dificuldade de reconstrução das ações de quem atirou a partir dos depoimentos, uma imputação individualizada, como dissemos, dependeria do exame de confronto balístico, que nunca foi realizado.

\section{O NÓ DA COMPETÊNCIA}

Seis dias depois de seu oferecimento, a denúncia foi recebida pelo juiz auditor da justiça militar, em decisão que dá início à ação penal perante a Justiça Militar do Estado de São Paulo. Durante o processo penal militar, foram realizadas 36 audiências de interrogatório, além de audiências para oitiva de 51 testemunhas.
[41] Fls. 4101-4103.

[42] A denúncia é a peça inicial da ação penal e estabelece quais pessoas, por quais fatos e violando quais normas serão submetidas ao processo criminal. Tendo em vista o advento da Lei Bicudo, a denúncia da justiça militar foi posteriormente encaminhada à justiça comum que confirmou o arranjo entre fatos, pessoas e normas violadas ao pronunciar todos os réus, e pelos mesmos crimes, que haviam sido denunciados pelo promotor de justiça militar.

[43] Fls. 25-30.

[44] Coronéis Ubiratan Guimarães e Wilton Brandão, tenentes-coronéis Antonio Chiari, Luiz Nakaharada e Edson Faroro, e majores José Luiz Soares Coutinho e Gerson dos Santos Rezende.

[45] Fl.4055.

[46] Ubiratan Guimarães, Wilton Brandão, Antonio Chiari, Luiz Nakaharada e Edson Faroro.

[47] Fl.4101.

[48] "De efeito, admitiu e aceitou o Cel. Ubiratan o risco de produzir o danoso evento - anteviu o resultado e agiu. Percebeu que era possível causar o resultado e, não obstante, realizou o comportamento. Entre desistir da conduta - mesmo após iniciada a operação, onde já se desenhava a tragédia, com as rajadas de metralhadoras, etc. - e causar o resultado, preferiu que este se produzisse. Por conseguinte, responsabiliza-se o Cel. Ubiratan por todos os crimes dolosos contra a vida - consumados e tentados - ocorridos no Pavilhão - ' 9 ' da 'Casa de Detenção'” (fls. 25-30).

[49] "Extrai-se dos autos que a operação se desenrolou em duas etapas. Em sua primeira fase, os Policiais Militares, sob o total comando do Cel. Ubiratan e pertencentes aos grupos já individuados, procederam à retomada dos pavimentos" (fl.35).

[5o] Fl. 38 .

[51] Ronaldo Ribeiro dos Santos (2응 pavimento), Valter Alves Mendonça ( $3^{\circ}$ pavimento), Arivaldo Sérgio Salgado ( $4^{\circ}$ pavimento) e Wanderley Mascarenhas Souza (5ำ pavimento). 


\begin{tabular}{|c|c|c|c|c|}
\hline $\begin{array}{l}\text { FASE DE } \\
\text { ATUAÇÃO }\end{array}$ & $\begin{array}{l}\text { GRUPO/ } \\
\text { PESSOA }\end{array}$ & ATUAÇÃO & TROPA & VÍTIMAS \\
\hline \multirow{5}{*}{$\begin{array}{l}\text { Ia FASE DE } \\
\text { ATUAÇÃO: } \\
\text { "retomada" dos } \\
\text { pavimentos }\end{array}$} & GRUPO I & $\begin{array}{l}\text { Retomada do } 2 \text { - pavimento } \\
\text { ( } 1 \text { - andar) }\end{array}$ & $\begin{array}{l}\text { ROTA (Rondas Ostensivas Tobias de Aguiar): } \\
\text { Ronaldo Ribeiro dos Santos + } 26 \text { PMs }\end{array}$ & 15 mortos \\
\hline & $\begin{array}{l}\text { GRUPO } 2+ \\
\text { LUIZ NAKAHA- } \\
\text { RADA }\end{array}$ & $\begin{array}{l}\text { Retomada do } 3 \text { - pavimento } \\
\qquad(2 \circ \text { andar })\end{array}$ & $\begin{array}{l}\text { ROTA (Rondas Ostensivas Tobias de } \\
\text { Aguiar): Valter Alves Mendonça }+29 \text { PMs. } \\
\text { Luiz Nakaharada seria o responsável direto } \\
\text { pela morte de } 5 \text { presos na cela 339-E }\end{array}$ & 73 mortos \\
\hline & GRUPO 3 & $\begin{array}{l}\text { Retomada do } 4^{\circ} \text { pavimento } \\
\qquad\left(3^{\circ} \text { andar }\right)\end{array}$ & $\begin{array}{l}\text { COE (Comando de Operações Especiais): } \\
\text { Arivaldo Sérgio Salgado }+15 \text { PMs }\end{array}$ & \\
\hline & GRUPO 4 & $\begin{array}{l}\text { Retomada do } 5^{\circ} \text { pavimento } \\
\text { (4. andar) }\end{array}$ & $\begin{array}{l}\text { GATE (Grupo de Ações Táticas Especiais): } \\
\text { Wanderley Mascarenhas de Souza + } 12 \text { PMs }\end{array}$ & $\begin{array}{l}10 \text { mortos + } \\
3 \text { sobrevivem } \\
\text { (tentativa de } \\
\text { homicídio) }\end{array}$ \\
\hline & UBIRATAN & \multicolumn{2}{|c|}{$\begin{array}{l}\text { "Assumiu o total comando da operação" e "entre desistir da } \\
\text { conduta - mesmo após iniciada a operação, onde já se desenhava a } \\
\text { tragédia, com as rajadas de metralhadoras, etc. - e causar o } \\
\text { resultado, preferiu que este se produzisse." }\end{array}$} & $\begin{array}{l}\text { Todos crimes } \\
\text { dolosos contra a } \\
\text { vida (consumados } \\
\text { ou tentados): } \\
111 \text { mortes }+5 \\
\text { tentativas }\end{array}$ \\
\hline \multirow[t]{2}{*}{$\begin{array}{l}2 \text { a FASE DE } \\
\text { ATUAÇÃO: } \\
\text { "varredura" }\end{array}$} & GRUPO 5 & $\begin{array}{l}\text { Movimentação de descida } \\
\text { dos presos ao pátio e } \\
\text { subida às celas }\end{array}$ & $\begin{array}{l}32 \text { PMs no total (integrantes do Comando } \\
\text { de Policiamento de Choque e dos Batalhões } \\
\text { de Choque). Os Oficiais Superiores (com } \\
\text { exceção de Ubiratan) foram denunciados } \\
\text { pelos fatos descritos aqui. De acordo com } \\
\text { a denúncia, os oficiais omitiram-se ao } \\
\text { permitir a formação do "corredor polonês" }\end{array}$ & $\begin{array}{l}86 \text { lesões leves } \\
\text { e 1 grave }\end{array}$ \\
\hline & GRUPO 6 & $\begin{array}{l}\text { Movimentação de descida } \\
\text { dos presos ao pátio e } \\
\text { subida às celas }\end{array}$ & $\begin{array}{l}3 \text { PMs do 3 Batalhão de Choque, } \\
\text { conhecido como "Canil" }\end{array}$ & 9 lesões leves \\
\hline
\end{tabular}

Fonte: Elaboração das autoras.

[52] "Os presos, em sua movimentação de descida e subida dos pavimentos, eram forçados a passar por entre o chamado corredor polonês, formado por Policiais Militares. Nesse trânsito, foram espancados com instrumentos contundentes, recebendo, em sua maioria, golpes de cassetetes, sendo ainda agredidos a golpes de canos de ferro, de coronha de revólver e pontapés; alguns foram também feridos por instrumentos pérfuro-cortantes (facas, estiletes, baionetas) e mordidas de cachorro" (fl. 65).
Encaminhado o caso para julgamento pelo Conselho Especial da Justiça Militar, este se declara incompetente para julgar e remete o processo para a justiça comum. $O$ principal argumento para a decisão foi que, "pelos depoimentos colhidos a partir do segundo semestre de 1995 - ficou evidenciado o envolvimento, em tese, de autoridades civis legalmente constituídas à época". A decisão foi tomada após a promotora de justiça militar apontar que haveria indícios de crimes cometidos pelo então governador do Estado, pelo secretário de Segurança Pública e pelo assessor para Assuntos Penitenciários ${ }^{55}$. No entanto, nenhuma ação penal foi instaurada contra essas autoridades. 
Os autos foram então remetidos para o juiz da $2^{\text {a }}$ Vara do Tribunal do Júri de Santana, que, por sua vez, também se declara incompetente, afirmando ser da justiça militar a competência para julgar o caso. Suscita conflito negativo de competência, que tramita por nove meses no Superior Tribunal de Justiça. Nesse meio tempo a Lei Bicudo (Lei 9.299/1996) é aprovada, dispondo que os crimes dolosos contra a vida cometidos por militares contra civis passem a ser de competência da justiça comum. Em face da nova lei, o STJ determina a remessa dos autos à primeira instância da justiça comum e o andamento do processo na vara do júri é finalmente iniciado. Isso se dá meses antes de o cel. Ubiratan ser eleito deputado estadual, fato que suscita outro deslocamento da competência processual para julgamento, dessa vez em razão do foro especial.

A discussão sobre o juízo competente para julgar o caso é uma das questões que continuamente gerou controvérsia e demora no processo. Se a instrução processual, não obstante a complexidade do caso e de pessoas a serem ouvidas, tramitou em menos de quatro anos (entre IPM e ação penal militar), as discussões sobre o foro competente e as idas e vindas dos processos entre as instâncias e entre Câmara Criminal e Órgão Especial do TJSP geraram demora de mais de dez anos ${ }^{56}$.

A discussão sobre a competência para julgar o caso (justiça militar ou comum) que, como mencionamos acima, se deu antes da Lei Bicudo e paralisou o processo em sua fase inicial por quase um ano, retornou quando da pronúncia dos acusados para julgamento perante o Tribunal do Júri. Nesse momento, surgiu nova dúvida a respeito da competência desse tribunal para julgar os crimes de lesão corporal supostamente cometidos pelos réus. Como a Lei Bicudo determina o deslocamento da competência processual apenas em relação aos crimes dolosos contra a vida, o juiz da vara do Tribunal do Júri decidiu pela pronúncia dos acusados apenas em relação aos delitos de homicídio e determinou a competência da justiça militar para julgamento das lesões corporais. As defesas, então, pedem a nulidade dessa decisão ao Tribunal de Justiça, argumentando que a conexão entre os crimes de homicídio e lesões impõe julgamento único perante a justiça comum. O Tribunal de Justiça concorda, anula a decisão57 e outra pronúncia (praticamente idêntica à primeira)é elaborada, incluindo-se as lesões corporais. Esse debate e a reelaboração da decisão de pronúncia levaram aproximadamente dois anos.

Mas é a questão do foro por prerrogativa de função que se revela ainda mais problemática ao andamento do processo. Ubiratan toma posse como deputado estadual em 2 de janeiro de 1997, e, em razão da previsão de foro especial, o processo é desmembrado em relação a ele e encaminhado ao Órgão Especial do Tribunal de Justiça, que pede autorização ao Plenário da Assembleia Legislativa para processá-lo.An-
[53] Fl. 65 .

[54] Comoexemplo, temos ogrupo 2, do 3 - pavimento: trinta policiais $\mathrm{mi}-$ litares foram igualmente imputados pela morte de 73 presos, encontrados naquele pavimento.

[55] Ata de sessão de deliberação e decisão do Conselho Especial de Justiça, fls. $7673-7690$.

[56] Ver linha do tempo.

[57] TJSP,RESEOOT9994-20.1999.8. 26.0000, relator desembargador Egydio de Carvalho 
[58] O relator designado, desembargador Egydio de Carvalho, votou pela impronúncia de Ubiratan, mas foi vencido.

[59] TJSP, RESE 9137983-59.1998.8. 26.0000, p.11 do acórdão.

[6o] Voto vencido (relator Egydio de Carvalho): “[...] O certo, é, me parece, que o denunciado Cel. Ubiratan Guimarães não agiu com dolo eventual, como retratado na inicial e imputado nasentençadepronúncia[...] Enoque consistiu a atuação do Cel. Ubiratan Guimarães? Apenas a de dar ordens a seus subordinados" (TJSP, RESE 9137983-59.1998.8.26.0000). tes da resposta, em 2 de janeiro do ano seguinte, Ubiratan deixa o cargo eletivo e o processo é novamente encaminhado à primeira instância da justiça comum, que decide pela pronúncia. Esse trâmite (subida para TJSP e retorno) leva mais de um ano. Veremos a seguir o que se deu entre a decisão de pronúncia do cel. Ubiratan e o fim precoce de seu processo, em razão de sua morte em 10 de setembro de 2006.

\section{O JULGAMENTO DO CEL. UBIRATAN}

Após a decisão de pronúncia pela justiça comum de primeira instância, Ubiratan recorre à Seção Criminal do Tribunal de Justiça, que, por maioria, decide pela sua confirmação. Essa decisão determina que Ubiratan seja julgado pelo júri por cento e onze homicídios e cinco tentativas de homicídio. O desembargador Ângelo Gallucci, escolhido para redigir o acórdão $0^{58}$, afirma haver indícios de "exageros" desde o começo da operação, "quando se lembra do pesado armamento entregue aos comandantes da tropa, inclusive trinta e três metralhadoras carregadas e aptas para rajadas". De acordo com o desembargador, o "resultado final também parece demonstrar excesso: cento e onze presos morreram, sendo atingidos em regiões nobres de seus corpos (alguns por muitos disparos), enquanto que os militares alcançados por projéteis de armas de fogo receberam ferimentos em regiões anatômicas secundárias" 59 . Um dos três desembargadores foi "vencido", ao entender que Ubiratan não agiu com dolo eventual, ou seja, não assumiu o risco de nenhuma morte 60 .

Em junho de 2001, ocorre o julgamento pelo Plenário do Tribunal do Júri. O julgamento pelo júri funciona da seguinte maneira: após a exposição e discussão das provas e das teses de acusação e defesa em plenário, o juiz que preside a sessão formula uma série de quesitos que deverão ser respondidos pelos jurados, em regime de votação. As perguntas contidas nesses quesitos dizem respeito à verificação ou não pelos jurados dos elementos necessários à consideração de um ato como crime, de uma pessoa como seu autor e da necessidade de punir. Isso quer dizer que os jurados são perguntados sobre a comprovação de cada um dos elementos da conduta considerada crime, dos elementos que revelam a autoria e da existência ou não de alguma causa de exclusão de ilicitude ou de responsabilidade. Em tese, o juiz que preside o julgamento deve esclarecer os jurados acerca dos quesitos a serem respondidos e suas consequências. Há, no entanto, uma série de críticas sobre como se dava na prática esse procedimento, especialmente com relação ao fato de que muitas vezes os jurados, ao responderem sobre quesitos formulados em linguagem técnica, não estavam totalmente esclarecidos sobre o conteúdo e as consequências das respostas. Isso motivou mudança no sistema de quesitos e, a partir 


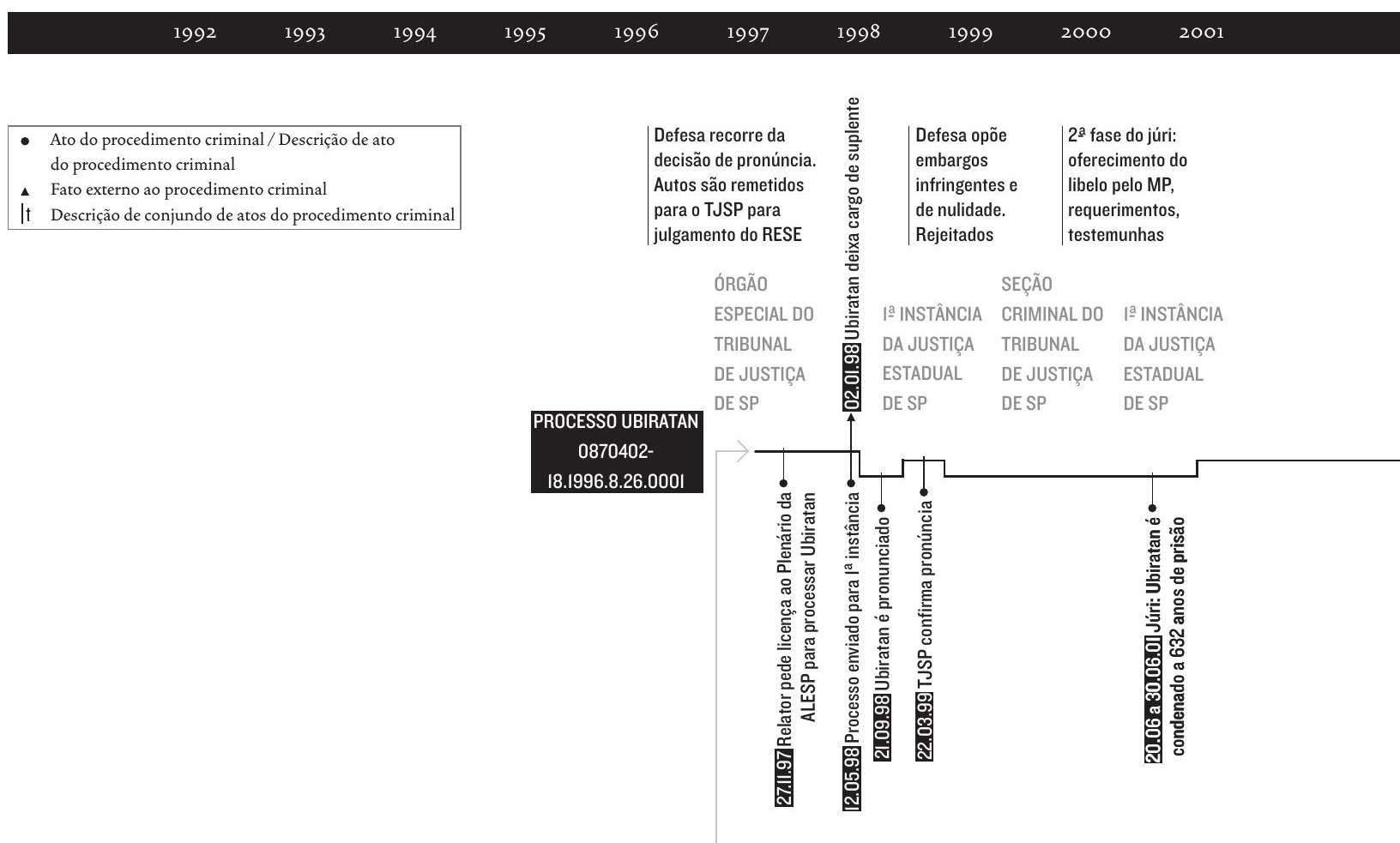

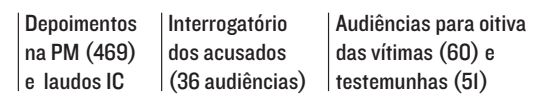

POLÍCIA MILITAR JUSTIÇA MILITAR

DO ESTADO DE SP DOESTADO DE SP

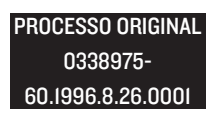

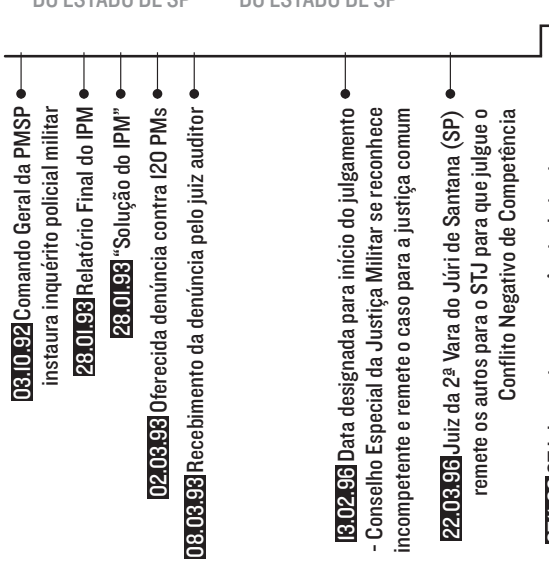
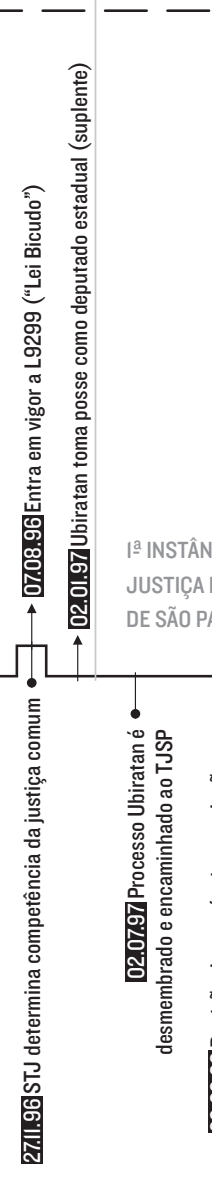

\begin{abstract}
Defesas recorrem da
decisão de pronúncia.

Autos são remetidos

para o TJSP para

julgamento do RESE
\end{abstract}

\begin{abstract}
São interpostos 10 recursos em sentido estrito (RESE) e duas apelações. MP oferece contrarrazões
\end{abstract}

a- INSTÂNCIA DA SEÇÃOCRIMINAL II INSTÂNCIA DA

JUSTIÇA ESTADUAL DO TRIBUNAL DE JUSTIÇAESTADUAL JUSTIÇA DE SP DE SÃO PAULO

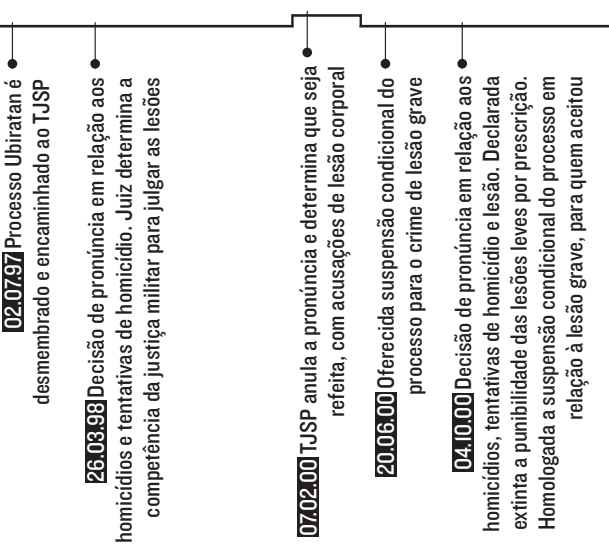


Interposição

de apelação

e remessa

dos autos

para o TJSP

SEÇÃO

CRIMINAL DO

TRIBUNAL

DE JUSTIÇA

DE SP
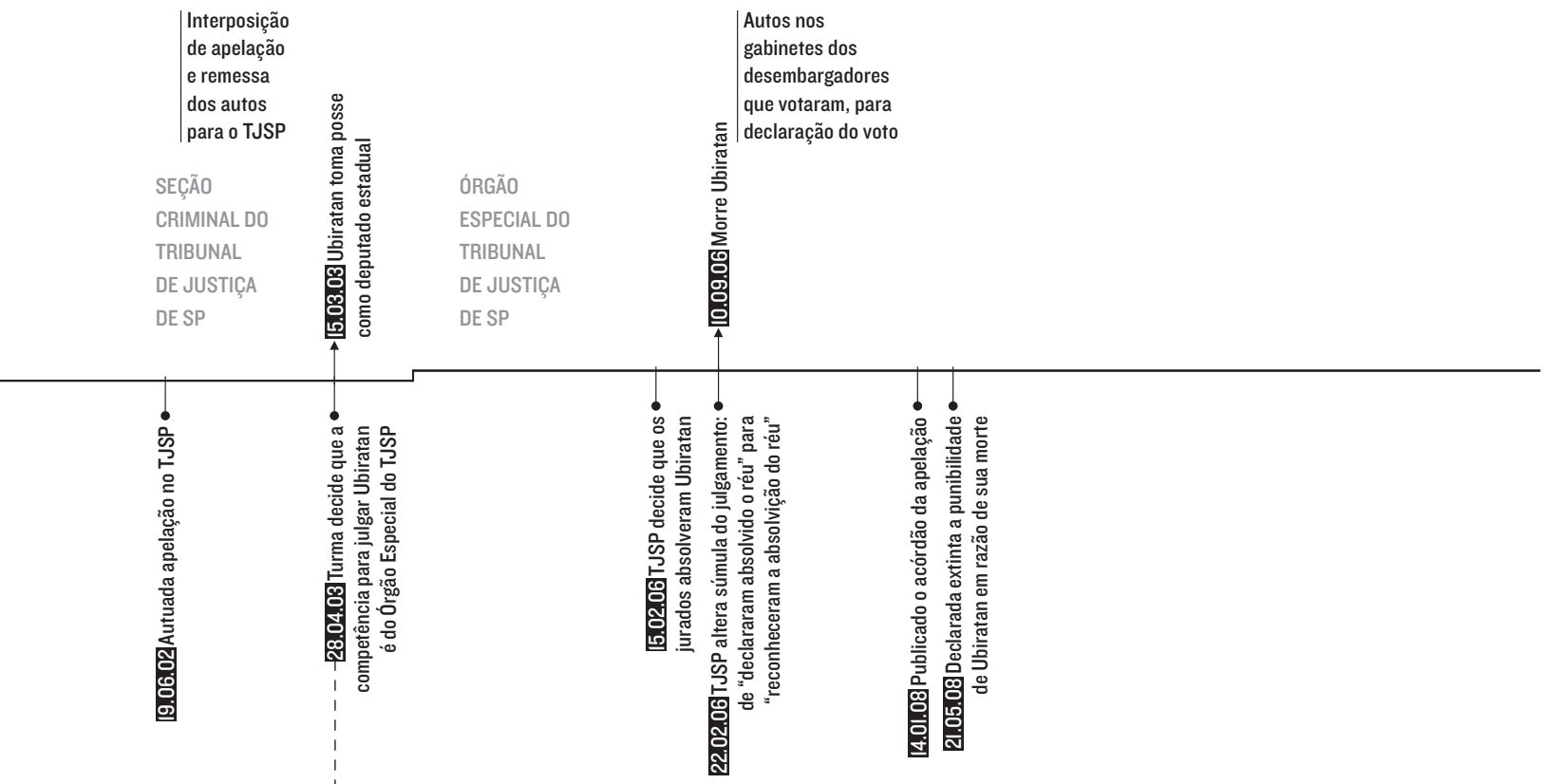

Aguarda-se

acórdão da apelação

de Ubiratan
Defesa opõe Embargos de Declaração

(rejeitados); interpõe recurso

especial e extraordinário (presidente do TJSP nega seguimento); interpõe agravos de instrumento.
SEÇÃO CRIMINAL

DO TRIBUNAL DE JUSTIÇA DE SP
ÓRGÃO ESPECIAL

DO TRIBUNAL DE JUSTIÇA DE SP
SEÇÃO CRIMINAL

DO TRIBUNAL DE

JUSTIÇA DE SP
I- INSTÂNCIA DA

JUSTIÇAESTADUAL DE SÃO PAULO

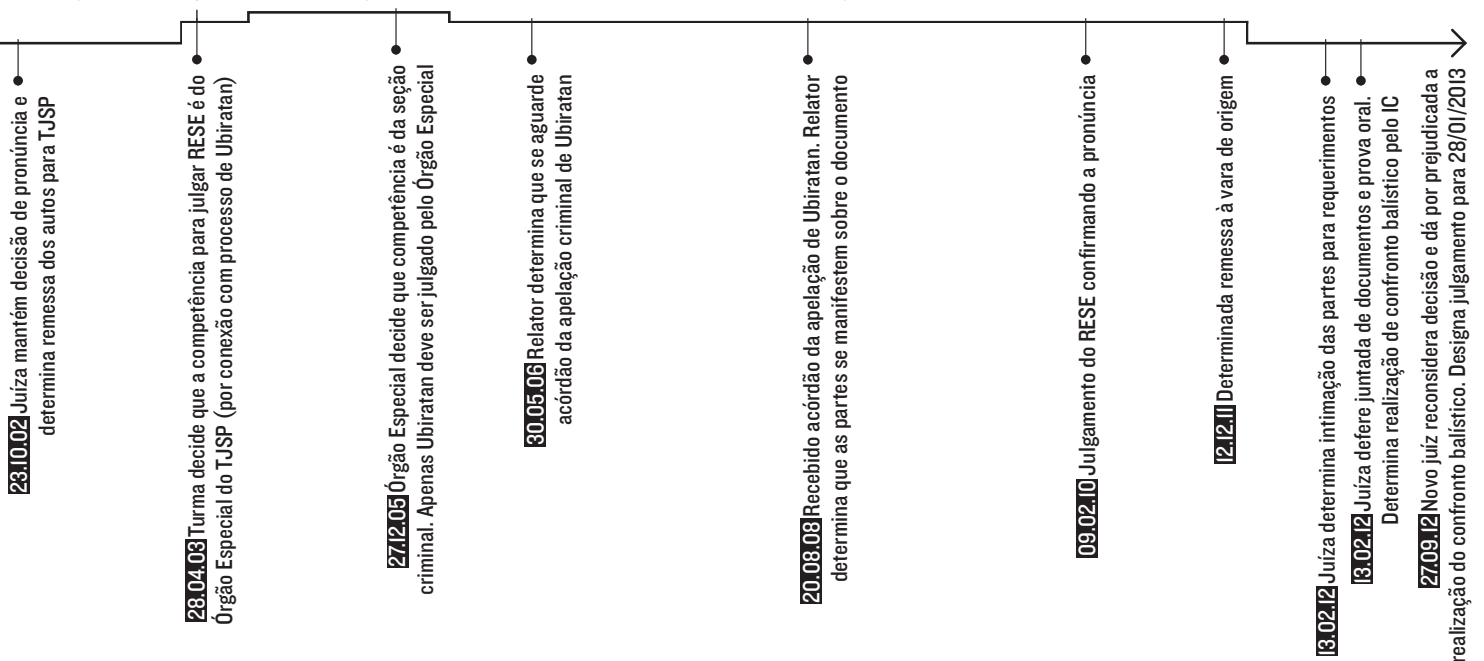


de 2008 , incluiu-se a pergunta "o jurado absolve o réu", com o objetivo de simplificar o questionário61. Não sabemos como se deu o julgamento em questão, uma vez que tivemos acesso apenas ao registro por escrito das respostas dos jurados. Nada podemos dizer sobre o grau de esclarecimento dos jurados, não obstante seja claro que houve, do ponto de vista das categorias técnicas da teoria do delito, contradição nas respostas dos quesitos.

Com relação ao caso, os jurados responderam sempre afirmativamente às questões sobre a ocorrência da ação dolosa por parte do cel. Ubiratan. Entretanto, em outro momento, responderam afirmativamente a duas circunstâncias que tecnicamente representam excludentes ou de ilicitude, ou de culpabilidade. Para que uma determinada conduta seja reconhecida como crime,é necessário o reconhecimento, grosso modo, das seguintes circunstâncias: a tipicidade objetiva, que consiste na adequação da conduta a um tipo penal e na sua vinculação ao resultado; a tipicidade subjetiva (intenção ou negligência); a inexistência de causas de exclusão de ilicitude (por exemplo, legítima defesa, estado de necessidade, estrito cumprimento de dever legal); a inexistência de excludentes de culpabilidade (por exemplo, ter o agente agido em erro sobre a proibição da conduta) ${ }^{62}$.

A "inexigibilidade de conduta diversa" é considerada pela doutrina e jurisprudência causa supralegal (porque não está expressamente prevista em lei) de exclusão de culpabilidade, e a ausência de culpabilidade impediria a condenação do réu. Quando perguntados sobre isso em relação aos homicídios consumados, os jurados responderam negativamente. Essa pergunta a respeito da "exigibilidade de conduta diversa" foi formulada da seguinte maneira: "era exigível que se esperasse conduta diversa da praticada, na situação em que se encontrava, para que não progredisse o referido conflito?".

Com relação aos homicídios tentados, os jurados responderam afirmativamente à pergunta sobre o "estrito cumprimento de dever legal" ("o réu praticou o fato no estrito cumprimento do dever legal, no exercício de suas funções para conter o conflito estabelecido?"). O estrito cumprimento de dever legal é considerado uma excludente de ilicitude, cujo reconhecimento também implicaria a impossibilidade de condenação.

No entanto, a resposta dos jurados aos quesitos seguintes implicou o reconhecimento de excesso doloso de Ubiratan na operação. Ao serem perguntados se "o réu excedeu dolosamente os limites do estrito cumprimento de dever legal", os jurados responderam que sim. Ou seja, os jurados entenderam que, embora tivesse agido em estrito cumprimento de dever legal, Ubiratan agiu, voluntariamente, de forma excessiva. O reconhecimento simultâneo dessas duas circunstâncias pelos jurados - estrito cumprimento de dever e ex-

\begin{abstract}
[61] "A necessidade de simplificação dos quesitos formulados aos jurados era uma unanimidade na doutrina. Não havia doutrinador que defendesse a manutenção do sistema anterior. Uma das grandes fontes de nulidade dos julgamentos do Tribunal de Júri era a existência de vícios na formulação dos quesitos (CPP, art. 564, II, k)." Badaró, Gustavo Henrique Righi Ivahy. "Tribunal do Júri". In: Moura, Maria Thereza Rocha de Assis (coord.) As reformas no processo penal: as novas leis de 2008 e os projetos de reforma. São Paulo: Revista dos Tribunais, 2008, p. 204.
\end{abstract}

[62] Para uma descrição do longo processo decisório e dos diferentes atores que participam da construção das categorias jurídicas na esfera penal, ver Machado, Marta R. A. e Machado, Maíra Rocha. "O direito penal é capaz de conter a violência?". In: Silva, F. G. e Rodriguez, J. R. (orgs.). Manual de Sociologia Jurídica. São Paulo: Saraiva (no prelo). 
[63] A pena-base de homicídio é aplicada no mínimo previsto em lei para o crime ( 6 anos) tanto no caso dos homicídios consumados como tentados. De acordo com a sentença, Ubiratan "é primário e não havendo outras causas que justifiquem o acréscimo da reprimenda", a pena deve ser fixada no mínimo. No caso dos homicídios tentados, a diminuição pela tentativa pode ser de $1 / 3$ a $2 / 3$. A juíza aplicou a redução de $1 / 3$ (pena de 4 anos para cada tentativa) porque considerou que muitas etapas do crime já haviam sido percorridas. A pena total alcançou 632 anos: 102 homicídios $x 6$ anos $=612$ anos; 5 tentativas $\mathrm{x} 4$ anos $=20$ anos. Por fim, 612 anos +20 anos $=632$ anos (fl. 12462).

[64] TJSP, AC 9127796-50.2002.8. 26.0000 .

[65] TJSP, AC 918287577.2003.8. 26.0000 .

[66] O acórdão é relatado pelo desembargador Egydio de Carvalho.

[67] A decisão foi por maioria de 20 votos contra 2 vencidos ( $O$ relator designado inicialmente, desembargador Mohamed Amaro, e desembargador Roberto Vallim Bellocchi).

[68] Na declaração de voto vencedor, lê-se a respeito da opção por absolver Ubiratan e não anular o julgamento: "Por que, todavia, em vez de dar o apelante como absolvido, não anular o julgamento popular, entendendo que os quesitos não foram bem formulados ou foram contraditórias as respostas? Porque os jurados efetivamente, na forma explanada, absolveram o coronel Ubiratan Guimarães. E, na forma da última preliminar, o que a defesa sustentou foi precisamente isso. Este Colendo Órgão Especial nada mais está fazendo do que, pelas respostas do Conselho de Sentença, desconsiderando, reitere-se, os quesitos atinentes ao excesso, tanto em uma quanto na outra série, entender que o réu foi absolvido. É a única decisão compatível com as afirmativas dos jurados" (TJSP, AC 9127796-50.2002.8.26.000o, p. 53 do acórdão). cesso doloso - éconsiderado incompatível pelo Tribunal de Justiça, como veremos abaixo.

Ubiratan é então condenado a 632 anos de prisão, por 102 homicídios e cinco tentativas de homicídio ${ }^{63}$, com o direito de apelar em liberdade.

Ubiratan é novamente eleito deputado estadual em 2003. O que estava em causa em seu processo quando de sua nova eleição era o julgamento de sua apelação no Tribunal de Justiça de São Paulo, que buscava reverter a decisão do júri. Sua apelação, recebida inicialmente pela Segunda Câmara Criminal do TJSP ${ }^{64}$ (competente no caso da tramitação comum), é encaminhada para julgamento pelo Órgão Especial do mesmo TJSP ${ }^{65}$ após sua eleição (competente para tramitar processos em foro especial) ${ }^{66}$. A apelação chega ao Órgão Especial em julho de 2003 eé julgada apenas em fevereiro de 2006: a maioria dos desembargadores interpreta a decisão dos jurados como sendo, na realidade, absolutória, e não condenatória.

O Tribunal de Justiça, em acórdão relatado pelo desembargador Walter de Almeida Guilherme, entendeu que os jurados absolveram Ubiratan ao reconhecer as excludentes de culpabilidade e ilicitude e que a juíza não respeitou a soberania do júri ao continuar as perguntas aos jurados ${ }^{67}$. Ou seja, entenderam que a pergunta sobre o excesso, uma vez já reconhecido o estrito cumprimento de dever legal, não deveria ter sido feita e por isso a anularam. A decisão gerou controvérsia, porque normalmente, em apelações, o Tribunal ou mantém a decisão dos jurados, ou anula o júri, determinando a realização de novo julgamento. Nesse caso - de forma atípica - o júri não foi anulado: sua decisão foi interpretada pelo tJsP de forma diferente do que entendeu a juíza que presidiu o julgamento. Segundo a justificativa do desembargador relator para o acórdão para a absolvição (e não anulação), já absolvido o réu diante do reconhecimento das excludentes, o certo seria considerar os quesitos seguintes prejudicados e encerrar a votação (antes do reconhecimento do excesso doloso) ${ }^{68}$.

Ainda segundo o desembargador Walter de Almeida Guilherme, caso o julgamento pelo júri fosse anulado, Ubiratan seria julgado no mérito (e não somente em apelação) pelo próprio Órgão Especial (e não mais pelo Plenário do Júri), já que na época voltara a ter foro especial. Nesse caso, afirma o desembargador, tudo indicaria que o Órgão Especial absolveria Ubiratan:

[...] Heresia, prognóstico insólito, insusceptivel de serfeito? Não. Simplesmente constatação da realidade. O julgamento é colegiado. Antes e durante a sessão, é óbvio, os Desembargadores tecem comentários, trocam opiniões. E, francamente, e talvez pela mesma maioria, o veredicto seria absolutório. Mas não direi isso. Seria ousadia. Um fato, contudo, é inegável se o Órgão 
Especial quisesse condenaro réu, não teria acolhido a preliminare, apreciando o mérito, lavraria decisão condenatória. Ora, se juridicamente se fazia impositivo dar guarida à preliminar e entender que o réu fora absolvido pelo júri popular, nada mais justo do que assim proclamar, não anulando o julgamento para que outro fosse proferido por esta Corte, cuja decisão, mais uma vez, ousando afirmar talvez sem poder, seria absolutória. ${ }^{69}$

Ubiratan é absolvido. Uma semana depois do julgamento da apelação, o Tribunal de Justiça altera a ementa do julgamento, de "declararam absolvido o réu no julgamento pelo Tribunal do Júri” para "reconheceram a absolvição do réu pelo Tribunal do Júri"7o.

Por mais de dois anos, os autos da apelação de Ubiratan caminham de gabinete em gabinete de desembargadores do Órgão Especial, já que muitos optaram por fazer a declaração de seus votos por escrito ${ }^{71}$. O acórdão é publicado apenas em 2008, quase um ano e meio depois da morte do cel. Ubiratan e, o processo foi extinto em seguida, sem recurso, em razão de sua morte.

O deslocamento de foro em relação ao cel. Ubiratan não apenas delongou o julgamento do seu processo como refletiu no processamento da ação originária que, após o desmembramento, continuou tramitando na primeira instância da justiça estadual paulista.É do que trataremos a seguir.

\section{DEZ ANOS NO TRIBUNAL dE JUSTIÇA DE SÃO PAULO}

Após a decisão de pronúncia dos 120 acusados em primeira instância, em 2000, foram interpostos dez Recursos em Sentido Estrito e duas apelações, recebidas pela Seção Criminal do TJSP em outubro de 2002. A discussão sobre a competência para julgar tais recursos - se caberia à Seção Criminal ou ao Órgão Especial leva aproximadamente três anos. Por fim, o Órgão Especial decide, citando jurisprudência dos Tribunais Superiores, que, embora seja competente para julgar o cel. Ubiratan, a conexão não implica foro especial para julgamento do processo original72. Após essa decisão, o processo segue para a Seção Criminal73, mas o relator, desembargador Barbosa de Almeida, determina que se aguarde a juntada do acórdão da apelação do processo do cel. Ubiratan, que estava durante todo esse tempo em fase de "declaração de votos" 74 . O referido acórdão é juntado ao processo apenas em agosto de 2008 e, em seguida, o relator determina que as partes se manifestem sobre o acórdão antes de levar os recursos a julgamento.

Os recursos são julgados apenas em fevereiro de 2010, dez anos após a pronúncia, em acórdão que a confirma integralmente 75 . Embargos de Declaração em relação a essa decisão são interpostos pela defesa
[69] TJSP, AC 918287577.2003 .8 .
26.0000, p. 55

[70] Publicação no Diário Oficial do Estado, de 22 de fevereiro de 2006. Retificação de súmula.

[71] O acórdão tem 197 páginas.

[72] O acórdão que declina competência para o Órgão Especial é relatado pelo desembargador Egydio de Almeida. O desembargador relator no Órgão Especial é Mohamad Amaro.

[73] TJSP,RESE 9196798-73.2003.8. 26.0000.

[74] Data de 30 de maio de 2006 o despacho do desembargador Barbosa de Almeida da Seção Criminal do TJSP determinando que se "providencie a juntada a estes autos do inteiro teor da decisão proferida pelo Col. Órgão Especial do Tribunal de Justiça no julgamento da apelação interposta pelo cel. PM Ubiratan Guimarães, que, originalmente, figurava no polo passivo da presente ação penal, posteriormente desmembrado com relação a este réu, devendo constar da respectiva certidão notícia de eventual trânsito em julgado". Em 7 de junho do mesmo ano, o referido desembargador profere o seguinte despacho: "1-Aguarde-se por trinta dias, já que a r. decisão proferida pelo Col. Órgão Especial desta Corte, pelo que se verifica do extrato de fls. $10.589 / 93$ ainda não foi definitivamente redigida, em razão, inclusive, das diversas declarações de votos. Decorrido o prazo fixado, proceda-se as novas buscas, informando o que de direito" (informações extraídas do sistema de acompanhamento processual do TJSP, pela internet).

[75] O acórdão é relatado pelo desembargador Salles Abreu. 
elevam mais um ano para serem julgados. Depois dessa longa tramitação no TJSP, os autos retornam à primeira instância em dezembro de 2011, para que se prossiga ao julgamento.

\section{VINTE ANOS DEPOIS: NINGUÉM É RESPONSABILIZADO}

Ao receber o processo, a juíza da vara do júri Laura de Mattos Almeida abre prazo para Ministério Público e defesa indicarem as testemunhas a serem ouvidas no Plenário e para eventual pedido de complementação probatória. Em junho de 2012, após pedido da defesa, a juíza determina a elaboração do laudo de exame de confronto balístico nos projéteis recolhidos e nas armas de fogo apreendidas. No entanto, no mês seguinte à decisão, o juiz José Augusto Nardy Marzagão assume o processo e, apenas cinco dias antes do "aniversário" de vinte anos do massacre, decide pela não realização do laudo (por motivos semelhantes aos das decisões anteriores nesse sentido) e marca o julgamento para 2013:

[...] À vista disso, indaga-se:qual a razão da existência de um processo que não produz quaisquer efeitos concretos no mundo naturalistico, ou seja, que nãotem qualquerfinalidade prática? Qual a razão de serdaexistência de um processo que permanece sem julgamento por 20 anos? A resposta nos parece óbvia... A rigor, torna-se imperioso o julgamento do presente feito.

Por um lado, esse exame permitiria determinar de qual arma se disparou o tiro ou os tiros que acarretaram a morte de qual detento e permitiria que se avançasse no processo de individualização de responsabilidade pelas mortes, o que, como mostramos acima, não se deu no momento da denúncia "por grupos". De outro lado, a reiterada afirmação de sua complexidade e dificuldade pelos peritos do Instituto de Criminalística é certamente um indicativo de que sua realização neste momento delongaria ainda mais o encaminhamento do processo ao plenário do júri para julgamento.

O risco de prescrição com a demora processual não é irrelevante nesse caso. Com exceção do crime de racismo e por ação de grupos armados, que nossa Constituição Federal considera imprescritíveis, nenhum dos demais crimes previstos na legislação penal brasileira pode ser investigado para sempre: a lei estabelece um prazo máximo para a atuação do sistema de justiça, chamado "prazo prescricional". No Brasil, o cálculo da prescrição está baseado na pena. Dependendo da etapa em que estiver o processo (antes ou depois de haver uma sentença definitiva), esta pena refere-se ao máximo de privação de liberdade atribuído pelo legislador ao crime ou à pena em concreto, isto é, decorrente da decisão do juiz no caso específico. O passo seguinteé 
verificar em quanto tempo uma dada pena prescreve. De acordo com o quadro de penas e prazos prescricionais previsto na lei, uma pena inferior a um ano prescreve em três, uma pena igual ou inferior a dois anos prescreve em quatro, e assim por diante, até penas iguais ou superiores a doze anos que prescrevem em vinte anos, o prazo máximo previsto na nossa legislação.

No processo do Massacre do Carandiru, como ainda não há sentença, o cálculo prescricional pode ser feito de duas formas: (i) em função da pena máxima atribuída a cada um dos crimes (e nesse caso o processo é extinto em relação às acusações prescritas) ou (ii) em função de uma projeção da pena que os réus receberiam, o que poderá ser confirmado apenas quando houver sentença. Esta última possibilidade é particularmente importante, pois a partir do momento em que houver a sentença e, portanto, a pena em concreto, o prazo prescricional pode diminuir sensivelmente, como mostra a tabela abaixo. Importante acrescentar que esses prazos são reduzidos à metade se, na data da sentença, o réu tiver mais de 70 anos de idade.

De acordo com o nosso sistema, esse prazo é contado via de regra a partir da data dos fatos, mas a própria lei estabelece que a conclusão de determinadas etapas do processo criminal faz com que o prazo seja interrompido e a contagem reiniciada a partir do ato ou decisão que o interrompeu. Por essa razão, um processo criminal pode durar por mais tempo que o prazo prescricional máximo de vinte anos, como no caso do Massacre do Carandiru.

O Quadro 3 apresenta as datas das interrupções do prazo prescricional - recebimento da denúncia, pronúncia e confirmação da pro-

QUADRO 2

Prazos prescricionais por imputação

\begin{tabular}{c|c|c|c}
\hline \multirow{2}{*}{ Imputação } & \multicolumn{3}{|c}{ Prazo prescricional } \\
\cline { 2 - 4 } & $\begin{array}{c}\text { Pena mínima e } \\
\text { máxima previstas } \\
\text { em lei }\end{array}$ & $\begin{array}{c}\text { Contado a partir } \\
\text { da pena máxima } \\
\text { prevista em lei }\end{array}$ & $\begin{array}{c}\text { Contado a partir } \\
\text { da pena mínima } \\
\text { (menor pena em } \\
\text { concreto possível) }\end{array}$ \\
\hline $\begin{array}{c}\text { Lesão leve } \\
\text { Lesão grave } \\
\text { homicídio } \\
\text { qualificado }\end{array}$ & 3 meses a 1 ano & 4 anos & 3 anos \\
\hline $\begin{array}{c}\text { Homicídio } \\
\text { qualificado } \\
\text { consumado }\end{array}$ & 12 a 30 anos & 12 anos & 4 anos \\
\hline
\end{tabular}


QUADRO 3

Possibilidades de ocorrência da prescrição

\begin{tabular}{|c|c|c|c|}
\hline Data dos fatos & $\begin{array}{l}\text { Recebimento da } \\
\text { denúncia }\end{array}$ & Pronúncia & $\begin{array}{l}\text { Confirmação } \\
\text { pronúncia }\end{array}$ \\
\hline 02.10 .1992 & 03.03.1993 & 04.10 .2000 & 09.02 .2010 \\
\hline $\begin{array}{l}\text { Lapso de tempo } \\
\text { transcorrido }\end{array}$ & 5 meses & $\begin{array}{l}7 \text { anose } \\
7 \text { meses }\end{array}$ & $\begin{array}{l}9 \text { anos e } \\
4 \text { meses }\end{array}$ \\
\hline $\begin{array}{l}\text { Crimes prescritos } \\
\text { pela mínima }\end{array}$ & Nenhum prescrito & $\begin{array}{l}\text { Lesão leve. } \\
\text { Lesão grave. } \\
\text { Homicídio } \\
\text { (tentado) para } \\
\text { quem fizer } 70 \text { anos } \\
\text { até a sentença }\end{array}$ & $\begin{array}{c}\text { Lesão leve. } \\
\text { Lesão grave. } \\
\text { Homicídio (tentado } \\
\text { e consumado) para } \\
\text { quem fizer } 70 \text { anos } \\
\text { até a sentença }\end{array}$ \\
\hline $\begin{array}{l}\text { Crimes prescritos } \\
\text { pela máxima }\end{array}$ & Nenhum prescrito & Lesão leve. & Lesão leve. \\
\hline
\end{tabular}

Fonte: Elaboração das autoras.

[76] Esse cálculo é feito a partir da pena máxima prevista, já que ainda não há sentença. núncia -, bem como o tempo decorrido entre eles. Ao confrontarmos os três lapsos de tempo com os prazos prescricionais calculados em função das penas mínimas e máximas (Quadro 2),é possível identificar quais crimes já prescreveram - ou estariam prescritos quando do advento da sentença.

Desse modo,é possível constatar que as 86 lesões leves que se referem às condutas dos réus durante a "varredura" prescreveram durante o processo. Já os crimes de homicídio podem aguardar sentença até 2026 para os réus que não tiverem completado 70 anos de idade até a data da sentençą76.

No entanto, após a sentença, o cálculo se dá de acordo com a pena em concreto, conforme explicado acima. Se considerarmos como parâmetro o cálculo de pena feito na sentença do cel. Ubiratan, em que todas as penas foram aplicadas segundo os mínimos possíveis (e depois multiplicadas pelo número de vítimas), é plausível imaginar que as penas dos demais réus de maior patente também o sejam. Nesse caso, já estariam prescritas, pelo tempo que decorreu entre pronúncia e sua confirmação (nove anos e quatro meses), além das 86 lesões leves já mencionadas, a lesão grave. Com a prescrição da lesão grave, seriam excluídos do processo os treze réus de maior patente, com exceção de Luiz Nakaharada: um coronel, dois tenentes-coronéis, quatro majores e cinco capitães. Para os réus que tiverem mais de 70 anos na data da sentença, também estarão prescritos os homicídios tentados e consumados. Luiz Nakaharada tem atualmente 67 anos e terá todos os crimes de que é acusado prescritos se não sobrevier sentença até abril de 2015. Os demais acusados por homicídio só completam 70 anos após 2020. 
Para todos aqueles que participaram das ações e não foram denunciados, o crime prescreveu ao completar vinte anos dos fatos em outubro de 2012. Isso porque, para estes, não ocorreu nenhuma causa interruptiva da prescrição, que é então contada da data do próprio fato. Isso vale para as autoridades públicas que foram mencionadas como tendo participado da decisão de invasão da Casa de Detenção, mas não foram incluídas na denúncia: o então governador Luiz Antônio Fleury Filho, o então secretário da Segurança Pública Pedro Franco de Campos e o então assessor para Assuntos Penitenciários da Secretaria de Segurança Pública Antonio Filardi. A participação dessas autoridades na decisão de invasão da Casa de Detenção foi expressamente apontada em trechos do relatório elaborado pelo Comando de Policiamento de Choque, 77 no Relatório Final do IPM $^{78} \mathrm{e}$ da própria peça inaugural da ação penal:

[77] Fls. 93-95.

[78] Fls.3650-3652.

Sequencialmente, o Cel. Ubiratan rumou à "Casa de Detenção", reunindo-se com [...] e mais com o Dr. Pedrosa e com os Doutores Fernando Antonio Torres Garcia e Ivo de Almeida, Juízes de Direito das Varas das Execuções Criminais e Corregedoria dos Presídios do Estado:Antonio Filardi Luiz, Assessor de Assuntos Penitenciários da Secretária de Segurança Pública e Élio Fernandes Nepomuceno, Coordenador dos Estabelecimentos Penitenciários do Estado. [...] Após breve diálogo, ato contínuo, o Cel. Ubiratan manteve conversação telefônica como Exmo. Secretário da Segurança Pública, Dr. Pedro Franco de Campos, expondo-lhe, com detalhes, que a situação era insustentável e deteriorava-se de forma célere. Ao ouvir tal relato, o Sr. Secretário determinou ao Cel. Ubiratan que fizesse uma avaliação total e final e se entendesse conveniente e oportuno - que ingressasse juntamente com a tropa no Pavilhão "9", visando conter a refrega, instaurando novamente a ordem e a normalidade. 79

[79] Fls.25-30.

A responsabilização do então governador Luiz Antônio Fleury Filho, do então secretário de Segurança Pública Pedro Franco de Campos e do então assessor para Assuntos Penitenciários da Secretaria de Segurança Pública Antonio Filardi foram cogitadas no julgamento da justiça militar, quando o Conselho Especial de Justiça da Primeira Auditoria reconheceu sua incompetência para julgaro processo, remetendo-o para a justiça comum:

a d. representante do Ministério Público pediu a palavra [...] Há indícios de responsabilidade, disse a Dra. Promotora, por parte do Sr. Governador do Estado; Secretário de Segurança pública; e do Dr. Filardi. O Dr. Antonio Cândido Dinamarco pediu a palavra para dizer que, parece que declinar de competência antes de decidir a instauração de ação penal contra tais autoridades é prematuro, pois somente após instaurada esta ação 
[80] Ata de sessão de deliberação e decisão do Conselho Especial de Justiça, fls. 7673-7690, 13/02/96.

[81] STJ, PET 651-SP, julgado emi6/10/96.

[82] Relatório 34/oo, item vi (conclusões), parágrafo 3 (grifos nossos).

[83] Relatório 34/oo, item viI (recomendações), parágrafo I (grifos nossos).

[84] Relatório 34/oo, item VII (recomendações), parágrafo 2.

[85] Relatório 34/oo, item VII (recomendações), parágrafo 3 .

[86] Para um panorama sobre a superpopulação prisional a partir das ações civis públicas julgadas pelo Tribunal de Justiça do Estado de São Paulo em 2011, ver Machado, Maíra. "A superpopulação prisional como obstáculo ao desenvolvimento sustentável". In: Oliveira, Carina e Sampaio, Romulo (orgs.). Instrumentos jurídicos para a implementação do desenvolvimento sustentável. Rio de Janeiro: FGV, 2012, p. 135-54.

[87] Os dados disponíveis no site da Secretaria de Administração Penitenciária do Estado de São Paulo são fragmentados por instituição prisional e não revelam séries históricas. Em virtude disso, utiliza-se aqui as informações disponibilizadas pelo Infopen, deveria ocorrer a declinação de incompetência. Novamente com a palavra a d. Promotora de Justiça, requereu naquele momento o envio de cópias de todo o processado ao Procurador Geral de Justiça, para apurar a responsabilidade de agentes civis. ${ }^{80}$

Como se tratavam de autoridades civis, com foro especial, o eventual processo deveria ser instaurado pelo procurador-geral de Justiça; por isso a requisição, pela justiça militar, naquele momento, de que fossem enviadas cópias dos procedimentos à referida autoridade. Não se tem notícia, contudo, até o presente estágio da pesquisa, de ação penal instaurada contra aquelas três pessoas: não há qualquer registro de ações contra eles no TJSP. Ao contrário, a pesquisa encontrou processo movido pelo ex-governador contra jornalista que publicou artigo afirmando sua participação no Massacre do Carandiru. O jornalista, em sua defesa, requereu que se iniciasse procedimento de exceção da verdade em relação ao crime de calúnia. A exceção foi julgada pelo órgão especial do STJ, que decidiu que "não restou comprovado o fato criminoso atribuído ao Dr. Fleury" ${ }^{\prime}$.

\section{E OS PRóXIMOS ANOS?}

As seções anteriores buscaram oferecer subsídios para o balanço da atuação do sistema de justiça ao longo dos vinte anos desde o Massacre do Carandiru. Ainda que as decisões do Tribunal do Júri venham a ser tomadas em tempo hábil para impedir a prescrição dos crimes de homicídio, importa ressaltar que a responsabilização, na esfera criminal, alcançará principalmente os policiais que à época do massacre encontravam-se nos níveis inferiores da hierarquia militar. Além do governador e dos secretários que, devido à ausência de formalização de acusação criminal, já tiveram seus crimes prescritos no início de outubro de 2012 , a leitura conjunta dos quadros 1,2 e 3 permite antever que muitos dos réus de maior patente em 1992 foram denunciados por crimes (lesão corporal) que também já prescreveram.

No âmbito da responsabilização disciplinar, é possível que nos próximos anos a observância da Lei de Acesso à Informação garanta o acesso público aos eventuais procedimentos iniciados pela própria Polícia Militar. A permanência de vários dos réus nos quadros da Polícia Militar paulista, associada à nomeação recente de ao menos dois deles para chefiar a Rota, reduzem as chances de que os procedimentos tenham sido concluídos e que decisões de responsabilização tenham sido tomadas. Ainda assim, o acesso à documentação existente - ou a afirmação, por parte da Corregedoria de Polícia Militar, de que não foram iniciados procedimentos disciplinares após o massacre -éal- 
tamente revelador do modo como a corporação percebe e reage aos eventos do dia 2 de outubro de 1992.

Aliada à ausência de responsabilização daqueles que, no front $\mathrm{da}$ operação ou no gabinete, permitiram a ocorrência do massacre, os processos civis de indenização pelos danos materiais e morais foram concluídos integralmente somente para vinte e seis dos familiares das 111 vítimas. Esses dois pontos já haviam sido explicitamente mencionados pela Comissão Interamericana de Direitos Humanos da OEA. Em abril de 2000, a Comissão tornou público relatório final em que afirma ser o Brasil "responsável [...] pela falta de investigação, processamento e punição séria e eficaz dos responsáveis e pela falta de indenização efetiva das vítimas dessas violações e seus familiares" 82 . Doze anos após o relatório, o cenário permanece o mesmo, e as três recomendações feitas ao Brasil na ocasião seguem urgentes.

Em primeiro lugar, a Comissão recomenda a realização de uma "investigação completa, imparcial e efetiva" e é bastante contundente sobre quem deve alcançar: "as autoridades e funcionários responsáveis pelas violações dos direitos humanos..." 83 .A depender do critério utilizado para definir “autoridade”, como visto acima, o Brasil já não é capaz de cumprir essa recomendação. Em seguida, a Comissão recomenda que o Brasil "adot [e] as medidas necessárias" para que as vítimas sejam "identificadas e suas famílias recebam adequada e oportuna indenização" ${ }^{4}$. Em que pesem os esforços dos defensores públicos que atuaram e atuam nesse caso, pouco mais da metade dos familiares dos 111 mortos tem suas ações de indenização acompanhadas pela Defensoria, e não há notícia de que os outros 92 cidadãos que sofreram lesões na data do massacre tenham sido indenizados pelo Estado.

Por fim, a terceira recomendação da Comissão refere-se ao desenvolvimento de "políticas e estratégias destinadas a descongestionar a população das casas de detenção, promover programas de reabilitação [...] e prevenir surtos de violência nesses estabelecimentos" 85 , entre outros pontos semelhantes. Ao contrário das duas recomendações anteriores, aqui o cenário modificou-se substancialmente nesses doze anos, infelizmente não no sentido indicado pela Comissão. As informações prestadas pelo Brasil à Comissão, no final da década de 1990 sobre a desativação do Carandiru e o plano de expansão do sistema penitenciário paulista, foram suficientes para que a Comissão, em suas conclusões, "reconhece[sse] que foram tomadas medidas para melhorar as condições carcerárias". Nos anos que se seguiram ao relatório, contudo, o quadro de superpopulação prisional no Estado agravou-se substancialmente ${ }^{86}$. Considerando os dados copilados pelo Infopen nos últimos sete anos, a população prisional no Estado passou de 138 mil presos (2005) para 180 mil presos (2011). Esse aumento do número de presos foi substancialmente maior do que o base de dados gerenciada pelo Ministério da Justiça a partir dos dados fornecidos pelos Estados. Os relatórios utilizados neste texto encontram-se disponíveis em http://portal.mj.gov. $\mathrm{br} / \mathrm{main}$. asp?View $=\% 7 \mathrm{BD}_{574} \mathrm{E}_{9} \mathrm{C}$ E-3 $\mathrm{C}_{7} \mathrm{D}-437 \mathrm{~A}-\mathrm{A} 5 \mathrm{~B} 6-22166 \mathrm{AD}_{2} \mathrm{E}$ $896 \% 7$ D \& Team $=$ \&params $=$ itemI $\mathrm{D}=\% 7 \mathrm{BC}_{37} \mathrm{~B}_{2} \mathrm{AE} 9-4 \mathrm{C} 68-4006-$ 8B16-24D28407509 $\mathrm{C} \% 7 \mathrm{D}$; \&UIP $\operatorname{artUID}=\% 7 \mathrm{~B}_{2} 868 \mathrm{BA}_{3} \mathrm{C}_{-1} \mathrm{C}_{72}-43-$ 47-BE11-A2 $6 \mathrm{~F}_{7} \mathrm{OF}_{4} \mathrm{CB}_{2} 6 \% 7 \mathrm{D}$, acesso em 10 de outubro de 2012).

[88] Para uma discussão sobre "os acontecimentos de maio" no âmbito da política penitenciária e de segurança paulista, ver Adorno, Sergio e Salla, Fernando."Criminalidade organizada nas prisões e os ataques do PCC". Estudos Avançados 21 (61), 2007.

[89] Report on the Human Rights of Persons Deprived of Liberty in the Americas (2011). Inter-American Commission on Human Rights.

[90] Para mencionar alguns episódios deste ano, cf.: Folha de S.Paulo, $10 / 10 / 2012$, "Justiça ouve acusados de formar 'tribunal do crime' em Ribeirão Preto", disponível em 〈http://wwwi.folha.uol.com.br/cotidiano/ribeiraopreto/1167103-justica-ouve-acusados-de-formar-tribunal-do-crime-em-ribeirao-preto. shtml); Folha de S.Paulo, "Após nova série de assassinatos, $\mathrm{PM}$ fará cerco na Baixada e Grande SP", disponível em 〈http://wwwl.folha.uol.com. br/cotidiano/1166912-apos-nova-serie-de-assassinatos-pm-fara-cerco-na-baixada-e-grande-sp. shtml ; Folha de S.Paulo, 10/10/2012, "Açãodepolíciaéumahipótese, dizAlckmin sobre assassinatos", disponível em <http://wwwi.folha.uol.com. br/cotidiano/1166917-acao-de-policia-e-uma-hipotese-diz-alckmin-sobre-assassinatos.shtml;; Folha de S.Paulo, 10/10/2012, "Só 3 dos 66 PMs mortos em SP no ano estavam em serviço", disponível em <http://wwwi.folha.uol.com. br/cotidiano/1166992-so-3-dos-6 6-pms-mortos-em-sp-no-ano-estavam-em-servico.shtml»; Folha de S.Paulo, 27/9/2012, "Violência policial", disponível em 〈http:// www1.folha.uol.com.br/colunas/ helioschwartsman/1159619-violencia-policial.shtml;; Folha de S.Paulo, 22/7/2012, "PM de SP mata mais que a polícia dos EUA", disponível em 〈http://wwwl.folha.uol.com.br/ fsp/cotidiano/55888-pm-de-sp-ma- 
ta-mais-que-a-policia-dos-eua. shtml>; Folha de S.Paulo, 8/10/2012, "Ativista vira ouvidora da polícia após denúncia de violência e ameaça", disponível em <http://wwwi.folha. uol.com.br/cotidiano/1165718-ativista-vira-ouvidora-da-policia-apos-denuncia-de-violencia-e-ameaca.shtml〉; UOL Notícias, 10/10/2012, "Testemunhas relatam execuções e cenas de terror em São Paulo", disponível em <http://noticias.uol.com.br/ultimas-noticias/ agencia-estado/2012/10/10/testemunhas-relatam-execucoes-e-cenas-de-terror-em-sp.htm>. Todas acessadas em outubro de 2012.

[91] Dentre as organizações mais atuantes estão a Pastoral Carcerária, a Rede 2 de Outubro, as Mães de Maio e a CEJIL.

[92] Citamos, exemplificativamente, os livros Estação Carandiru, de Drauzio Varella (1999), e Sobrevivente AndréduRap (doMassacre do Carandiru), de Bruno Zeni e José André de Araújo (2002); as músicas "Haiti", de Caetano Veloso e Gilberto Gil, "Diário de um detento", dos Racionais MC's, "Apologia ao crime", dos Detentos do Rap, "Manifest", do Sepultura; os filmes Carandiru, de Hector Babenco (2003), e O prisioneiro da grade de ferro, de Paulo Sacramento (2003); a instalação 111, de Nuno Ramos, exposta na Bienal de 1993; as peças de teatro Salmo 91, do diretor Djalma Thürler, e Apocalipse 1,11, do Teatro da Vertigem; o desfile de modas Talentos aprisionados realizado por Marcelo Sommer em 1999, dentro do Pavilhão 6 do Carandiru. aumento do número de vagas que, no mesmo período, foi de quase 89 mil para $100 \mathrm{mil}^{87}$. Ademais, desde a publicação do relatório da Comissão, assistimos à megarrebelião de fevereiro de 2001, aos eventos de maio de 2006 - no decorrer dos quais se contabilizou rebeliões em 73 presídios ${ }^{88}$-, além de vários outros relatos de violações sistemáticas de direitos humanos em instituições prisionais brasileiras pela Comissão Interamericana de Direitos Humanos ${ }^{89}$. O cenário que acabamos de expor justifica, no mínimo, preocupação com a capacidade de nossas instituições de reagir a esse evento. Não apenas em razão da ineficácia dos nossos mecanismos de atribuição de responsabilidades e de reparação, mas porque as condições objetivas presentes na época do massacre ou persistem ou se agravaram. Referimo-nos aqui tanto ao panorama do sistema carcerário como aos frequentes relatos de atuação violenta da Polícia Militar no estado de São Paulo99.

De outro lado, identificamos esforços de reflexão, narrativa, denúncia e construção de sentido para o que aconteceu na tarde do dia 2 de outubro de 1992 vindos da sociedade civil, por meio da atuação de organizações não governamentais ${ }^{11}$ e da produção literária, musical, acadêmica e cinematográfica ${ }^{2}$. Provavelmente essa via segue sendo a mais promissora se pretendemos assumir a nossa responsabilidade pela transformação desse cenário.

LUisa Moraes Abreu FerReiraé pesquisadora do Núcleo de Estudos sobre o Crime e a Pena da Escola de Direito de São Paulo da Fundação Getúlio Vargas e mestranda em direito penal pela Faculdade de Direito da Universidade de São Paulo (luisaferreira@gmail.com).

MARTA RODRIGUEZ DE Assis MACHADO é pesquisadora do Núcleo de Estudos sobre o Crimee a Pena da Escola de Direito de São Paulo da Fundação Getúlio Vargas, professora na mesma instituição e pesquisadora do Cebrap (marta.machado@fgv.br).

MAÍrA ROCHA MACHADO é pesquisadora do Núcleo de Estudos sobre o Crime e a Pena da Escola de Direito de São Paulo da Fundação Getúlio Vargas e professora associada na mesma instituição (maira.machado@fgv.br). 